\title{
A Stepwise Approach to Beach Restoration at Calabaia Beach
}

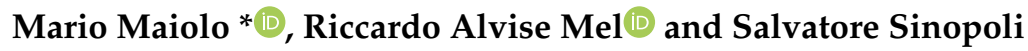 \\ Environmental Engineering Department (UNICAL-DIAm), Capo Tirone Experimental Marine Station, \\ University of Calabria, 87036 Rende, Italy; riccardo_alvise.mel@unical.it (R.A.M.); \\ salvatore.sinopoli@unical.it (S.S.) \\ * Correspondence: mario.maiolo@unical.it; Tel.: +39-984-496556
}

Received: 27 August 2020; Accepted: 19 September 2020; Published: 24 September 2020

\begin{abstract}
Sea hazards are increasingly threatening worldwide coastal areas, which are among the most strategic resources of the Earth in supporting human population, economy and the environment. These hazards enhance erosion processes and flooding events, producing severe socio-economic impacts and posing a challenge to ocean engineers and stakeholders in finding the optimal strategy to protect both the coastal communities and the health of the environment. The impact of coastal hazards is actually worsened not only by an enhancing rate of relative sea level rise and storminess driven by climate changes, but also by increasing urban pressure related to the development of the sea economy. With regard to larger environmental awareness and climate change adaptation needs, the present study focuses on a stepwise approach that supports the actions for coastal protection at Calabaia Beach, which is located in the Marine Experimental Station of Capo Tirone (Cosenza, Italy). These actions first aim to protect humans and coastal assets, then to restore the environment and the local habitat, overcoming the need for the emergency interventions carried out in the last decades and pointing out that healthy ecosystems are more productive and support a sustainable marine economy ("Blue Growth").
\end{abstract}

Keywords: coastal erosion; coastal engineering; coastal management; nature-based solutions; boulders in bulk; beach nourishment; Posidonia oceanica

\section{Introduction}

Coastal areas sustain the Mediterranean human population [1]. These areas are complex socio-ecological systems, based on a strong relationship between human activities and natural processes [2], where human activities when using the coastal resources should conserve their resilience and the services they can provide to local communities [3-6]. The increasing demand for the use of the sea, such as facilities for energy production, extraction of materials from submarine quarries for building and beach nourishment, shipping and fishing activities, tourism, aquaculture, marine cultural heritage, and ecosystem and biodiversity conservation, along with the multiple pressures threatening the coastal resources, requires an integrated planning and management approach (see Directive 2014/89/EU). The Mediterranean region should pursue a long-term strategy to support a sustainable development of the economy based on the use of the sea for innovative and sustainable purposes (Blue Growth) [7,8]. Despite the great opportunities that Blue Growth offers, coastal areas regularly face several geopolitical, economic and environmental challenges which are worsened by climate change, subjecting the vulnerable areas of the Mediterranean Sea to large economic and environmental loss and damage [9-16]. In particular, flooding and coastal erosion processes are enhanced by climate changes, which can produce additional hazards than those attributable to sea level rise alone [17-24]. Moreover, since increasing urban pressure will further exacerbate these hazards, there is a clear need 
for a joint initiative to promote integrated economic actions aimed to preserve the ecosystems and the biodiversity of the Mediterranean Sea [25-27].

In recent decades, coastal protection interventions have been planned following major sea calamities, but only focusing on the safety and protection of humans and economic resources, without taking into account the environmental needs of the land [28,29]. Nowadays, several maritime policies aim to protect coastal habitats and natural resources, promoting a sustainable use of land [30-32], following the guidelines of the sustainable development goals of Agenda 2030, the United Nations Environment Assembly (UNEA-4, 2019, Nairobi, Kenya) and the Intergovernmental Conference (New York, 2019) concerning the law of the sea. The European Union promotes Blue Growth following the Treaty 2002/413/CE ICZM (Integrated Coastal Zone Management), the Directive 2008/56/CE (Marine Strategy Framework Directive, MSFD), the Commission Decision 2010/477/UE and the Directive 2014/89/UE, supporting an integrated and cross-sectorial sustainable management of coastal areas to promote the restoration of the environment and the ecosystem (i.e., nature based solutions, NBS) [33]. In this context, it is of paramount importance to address the effects of local human action on the environment [34,35], supporting the evaluation of the vulnerability of the area [36,37].

Despite recent policies, environmental degradation still threatens coastal communities, mostly due to the impact of the rigid structures built in the last decades [38,39], which affect landscape, ecosystems, biodiversity and biological interactions [40-42]. Therefore, shifting from hard structures towards environmentally-friendly interventions and NBS is crucial in the development of a sustainable sea economy [43-48]. Although NBS are certainly an improvement with respect to previous approaches that did not consider the multiple needs of the environment, certain interventions aiming to restore coastal ecosystems failed in their purpose, since bio-geomorphic feedbacks inherent to ecosystems were not analysed sufficiently. Moreover, NBS are often expensive, making any possible failures a huge issue to deal with for stakeholders. Thus, any restoration measure has to be evaluated on the basis of the specific nature of the area.

The coastal area of Belvedere Marittimo provides a significant example concerning sea-defence structures designed in turn to protect the Calabaia Beach, located in the Marine Experimental Station of Capo Tirone (Belvedere Marittimo, Cosenza, Italy, $39^{\circ} 36^{\prime} 13^{\prime \prime} \mathrm{N}, 15^{\circ} 51^{\prime} 24^{\prime \prime} \mathrm{E}$ ). This area is crucial in planning scientific activities concerning the Blue Growth, with particular reference to the study of local hydrodynamics, coastal protection measures, dispersion of pollutants and marine biology. Since Calabaia Beach has been affected by erosion processes for decades [49-51], several hard structures were designed in the late 20th century, subsequently converted into submerged breakwaters fixing a nourishment cell. Actual plans promote NBS through the use of Posidonia oceanica, a native seagrass which reduces wave power and restores coastal areas [52-56], following policies of good environmental management and sustaining the development of Blue Growth [57-59].

Here we illustrate the stepwise approach adopted at Calabaia Beach, which aimed to restore the environment while protecting maritime and coastal assets, shifting from hard interventions to NBS. The case study of Calabaia Beach is a representative example of how sea hazard and environmental protection can be pursued together. The paper first describes the sea defence structures widely used in coastal protection, with particular reference to Calabaia Beach. A brief characterization of the area and of the approach is provided in Section 2. Section 3 describes the effectiveness of the interventions carried out at Calabaia Beach in recent decades, moving from measures that aim to mitigate sea hazards but only protecting humans and goods to measures that also pursue the restoration of the environment, with particular reference to innovative environmentally-friendly solutions. A set of conclusions closes the paper. 


\section{Materials and Methods}

\subsection{Costal Erosion Management: A Time Dependent Approach}

Beaches are complex systems requiring a multidisciplinary design and management approach. Actions aimed at challenging the erosion process have to be designed on the basis of the specific characteristics of the land. Morphological features, together with the economic and environmental needs of the area and the climate change scenario, are fundamental in choosing a coastal protection strategy, as stated in the EUROSION report [31]. Five adaptation strategies could be pursued:

- do nothing: no changes with respect to the existing situation;

- managed realignment: land-use planning, recovering areas from sea flooding;

- $\quad$ hold the line: sea defence measures supporting the former defence line;

- move seaward: sea defence measures promoting an advancement toward the sea of the defence line;

- limited intervention: non-invasive measures to support natural processes in reducing flood hazards and erosion processes.

Action planning is strictly related to the time scale of the hazard and to the priority of the needs of the area $[8,35,60]$. Floods, erosion processes and damage to the assets of coastal settlements that occur with a single storm surge can be counteracted only by means of hard structures, which are, on the one hand, effective in facing sea hazards but, on the other, inadequate for the environmental needs of the land. Conversely, sea hazards driven by climate change show a long-term evolution and can be counteracted by means of environmental-friendly measures that restore the coastal environment. Figure 1 summarizes measures widely used in coastal defence.

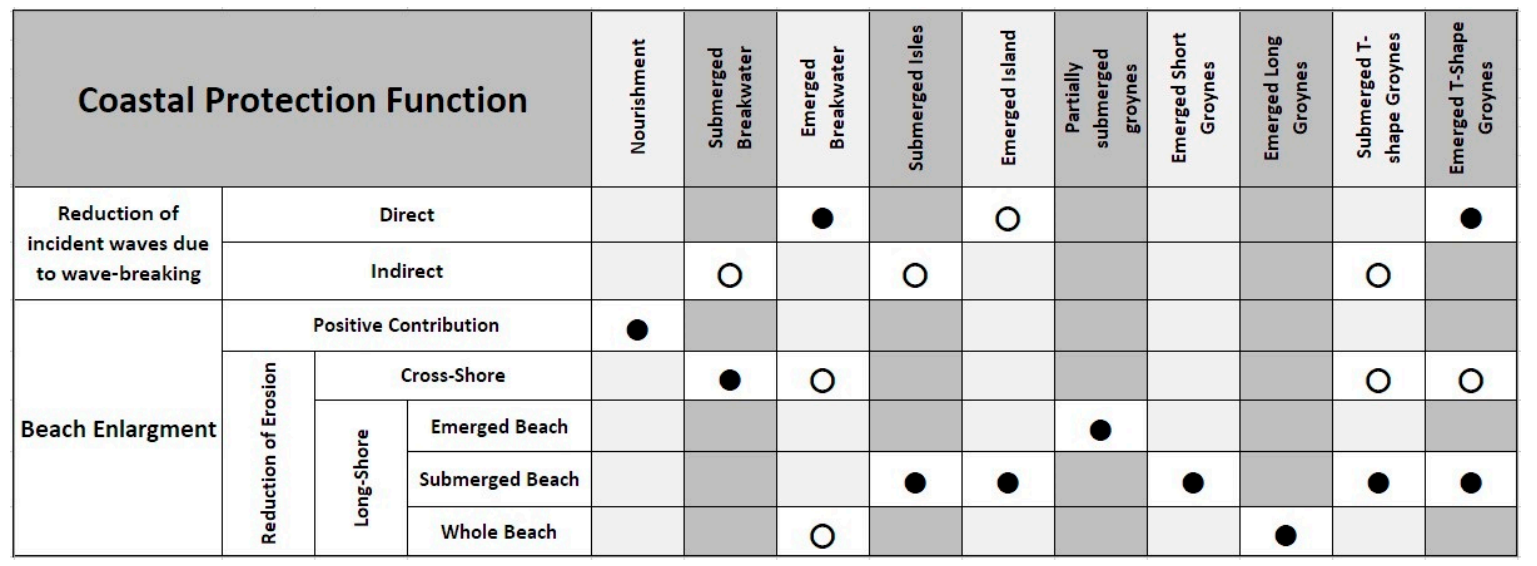

Figure 1. Example of coastal defence measures and their main effects. Black dots stand for direct effects; white dots for indirect effects.

Coastal protection arises from the need to identify the optimum time-dependent approach to sea hazard management. Although erosion processes occur gradually, at a certain time shoreline buildings are suddenly threatened due to the lack of adequate sea defence measures (i.e., the do nothing option). In such a threat, it is not possible to plan long term actions since the intervention must be aimed at protecting assets within the shortest time. On the other hand, when the erosion process has been contained, the stakeholders have enough time to promote long-term planning, evaluating the sustainability and the durability of different solutions and taking into account all the needs of the land (Figure 2).

When the progression of the erosion process threatens humans and goods, stakeholders have no time to plan an intervention that satisfies all the needs of the coastal area, limiting the action to containment measures (i.e., the hold the line option). In this condition, hard defences (e.g., seawall and 
bulk boulder breakwaters, Figure 3a) provide a rapid solution in protecting the shoreline but affect the landscape, triggering the erosion process and requiring high maintenance costs [28,61,62].

Soft defences (i.e., the move seaward option) are usually less efficient than hard structures in flood protection, but they are increasingly supported by international standards due to their low costs and impacts on landscape, local habitat and the marine ecosystem. Perched nourishments are the most popular example of soft defences (Figure 3b), which aim to nourish and fix the shoreline by reproducing the original slope of the seabed and achieving the natural equilibrium profile of the beach after each storm [63-73].

\section{Management options}

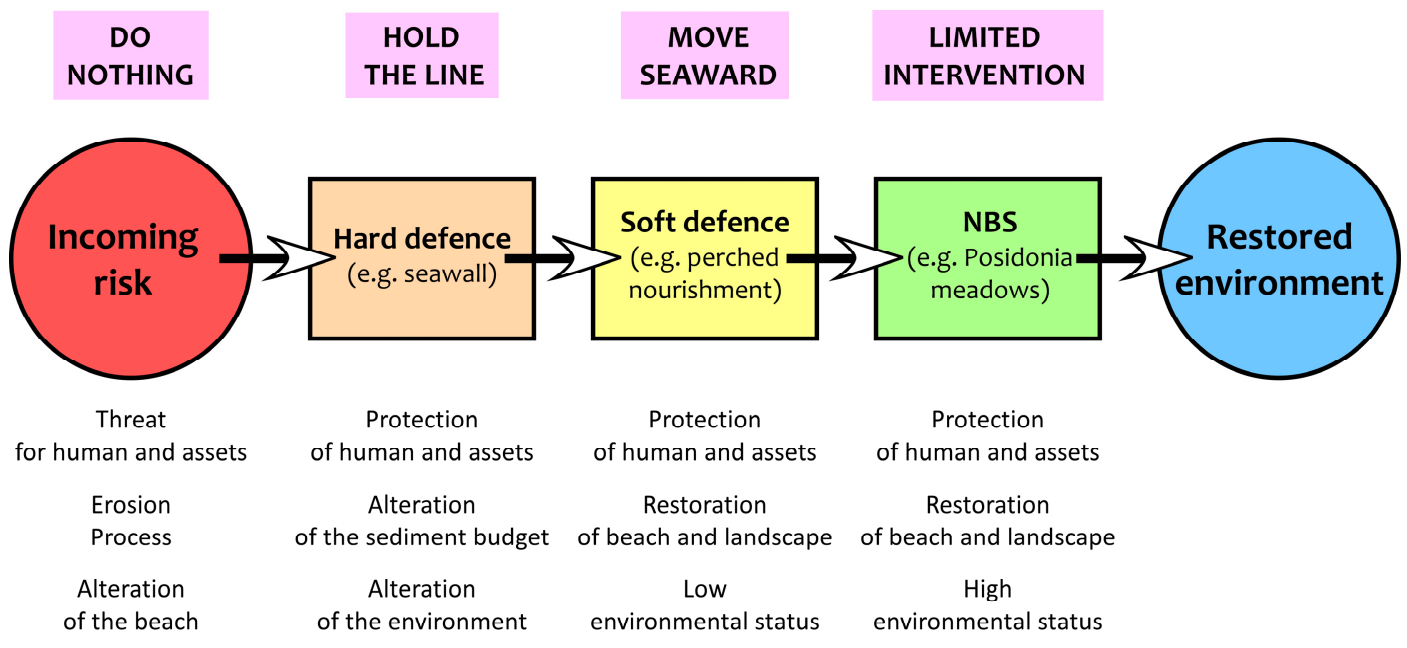

\section{Main outcomes}

Figure 2. Summary of the stepwise approach in coastal defence.

(a)

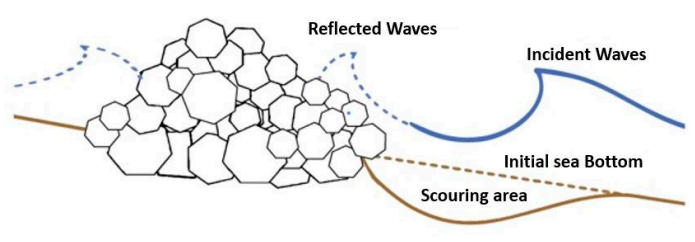

(c) (b) Cross-shore section for a perched nourishment

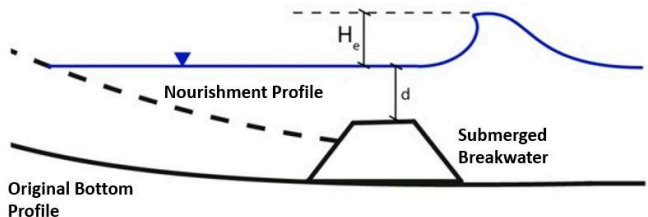

(d)

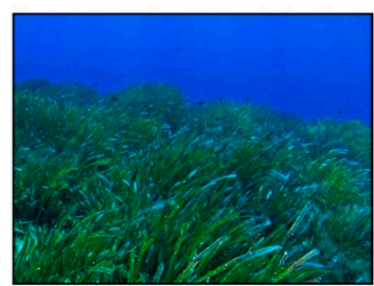

Posidonia Meadows

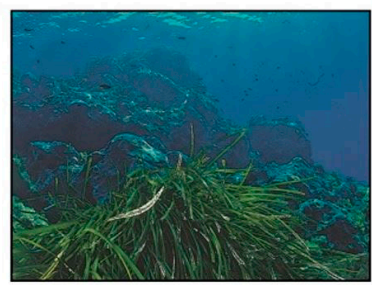

Figure 3. Examples of coastal defence interventions. (a) longitudinal view of a breakwater made of bulk-boulders; (b) transversal section of a submerged breakwater; (c) interaction between natural elements of the shoreline and waves; (d) Posidonia oceanica meadows located at the Experimental Marine Station of Capo Tirone. Photographer F. Sesso. 
The evolution of soft defences is represented by NBS, usually classified as a limited intervention option and largely used to counteract the erosive processes produced by former rigid measures [72-76]. NBS consist of a wide range of interventions (e.g., cobble berm, dunes, mangroves), depending on the features of the local environment [72]. Wave height reduction produced by NBS is comparable to wave height reduction achieved by artificial breakwaters [71] but NBS are usually cheaper [72]. The strength of NBS is to achieve the goals of the limited intervention option, by enhancing the resilience of the coastal marine environment. First, NBS are supported by anthropic action, further becoming an ecosystem capable of developing and becoming self-supportive (Figure 3c). A good example in the Mediterranean area is provided by the Posidonia oceanica meadows (Figure 3d) [77-82]. Posidonia oceanica meadows can serve multiple purposes, by offering an additional resistance to the hydrodynamic action, promoting biodiversity and environmental resilience $[57,58]$ and increasing the self-purification of the sea [80,83]. In addition, Posidonia oceanica reduces the need for further coastal interventions [59] and supports Blue Growth.

As a footnote, we stress that the number of measures in the stepwise approach depend on the beach conditions (e.g., NBS only for well-preserved beaches; more interventions for degraded shorelines).

\subsection{Calabaia Beach}

Here we focus on Calabaia Beach, located in the southern Tyrrhenian Sea (Figure 4). The morphology of the southern Tyrrhenian coast is mostly characterized by metamorphic and sedimentary rocks directly extending to the sea and narrow coastal plains.

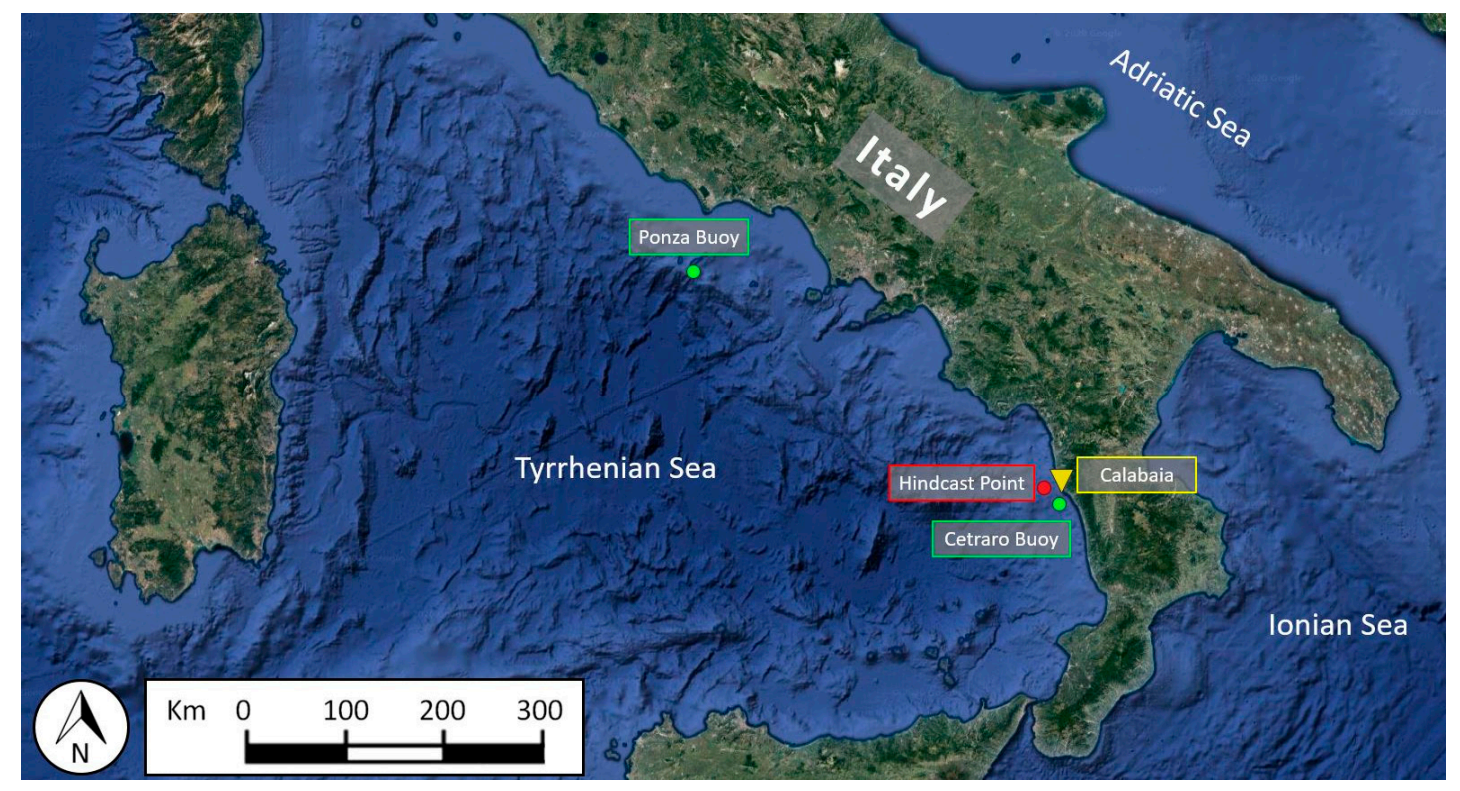

Figure 4. Location of Calabaia in the Tyrrhenian coast.

\subsubsection{Bathymetric and Topographic Surveys}

Since the 1960s, the Southern Tyrrhenian shoreline has been intensively developed, enhancing erosion processes (Figure 5) and requiring the building of many sea defence structures $[48,84,85]$. Watercourses formerly conveyed fine-grain material to the coast, balancing the erosion process. However, the urbanization of the coast, with particular reference to the Salerno-Reggio Calabria railway, reduced sediment supply from the rivers to the coast, demanding a continuous maintenance effort against erosion. 
(a)

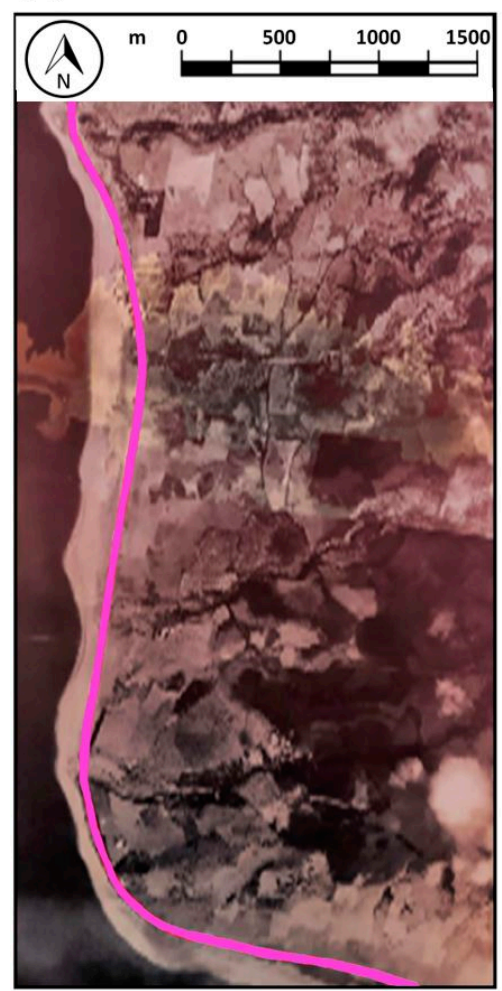

(b)

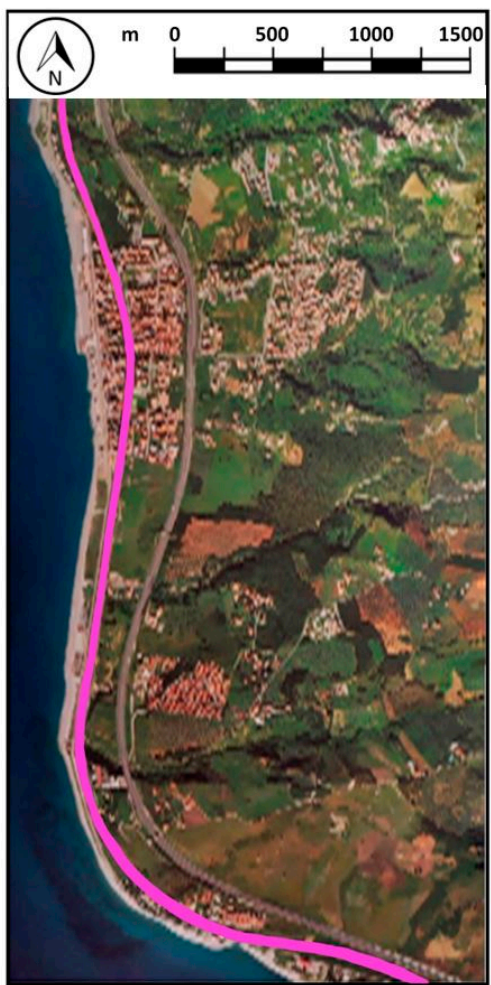

Figure 5. Evolution of Tyrrhenian coastline, from Nocera Terinese to Gizzeria: (a) Royal Air Force (RAF) image taken in August 1943. Pink line shows the railway. (b) Satellite image taken in June 2008. Yellow line represents the railway.

Based on studies performed by the U.S. Coastal \& Hydraulics Laboratory (CHL), the Army Corps of Engineers and the Pavia Environmental Engineering Study Center (CSDIA), the southern Tyrrhenian coast can be divided into 11 coastal cells (Figure 6). Calabaia Beach, which belongs to cell D, had eroded considerably until the mid-1970s (Figure 6a). The hard defences built during the 1980s stopped the retreat of the shoreline (Figure 6 b).

Further bathymetric surveys were carried out from 2005-2008, based on World Geodetic System 1984 data and two cornerstones (Figure 7), the CS1 $\left(39^{\circ} 35^{\prime} 58.9871^{\prime \prime} \mathrm{N}, 15^{\circ} 51^{\prime} 37.6292^{\prime \prime} \mathrm{E}\right)$ and the CS2 $\left(39^{\circ} 37^{\prime} 00.8050^{\prime \prime} \mathrm{N}, 15^{\circ} 51^{\prime} 06.6870^{\prime \prime} \mathrm{E}\right)$. In some sections, the surveys were performed perpendicular to the shoreline, from the railway to $10 \mathrm{~m}$ sea depth. The collected data have been further compared to address the effects of the sea defence works on the evolution of the shoreline (Figure 7) [86]. 

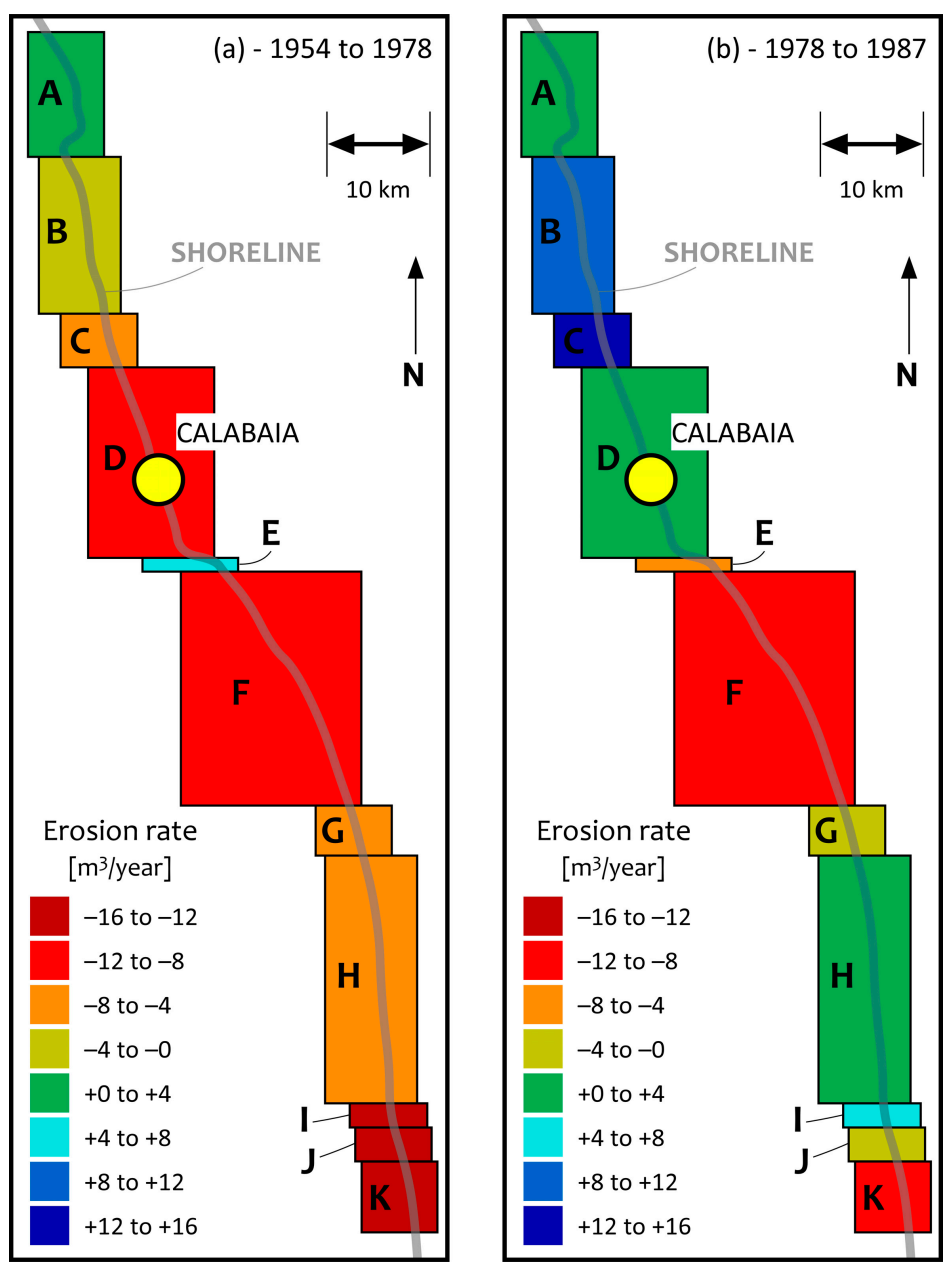

Figure 6. Historical sediment balance along the southern Tyrrhenian coast from Tortora (located in the northern boundary of the Calabria region) to Lamezia Terme, performed by CHL and CSDIA. The panels show the eroded volume in each cell of the shoreline in two different periods: 1954-1978 (a) and 1978-1987 (b). Calabaia Beach belongs to the cell D.

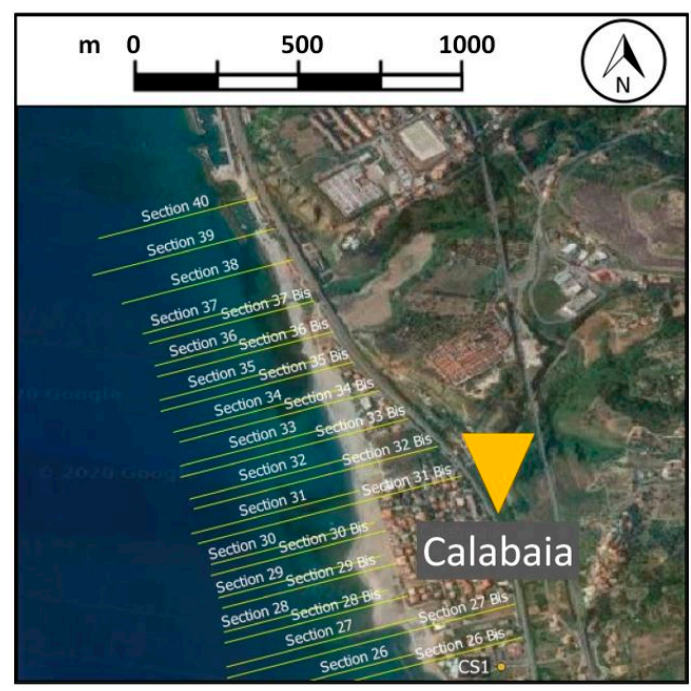

Figure 7. Location of the cross-sections used in the bathymetric and granulometric surveys. 


\subsubsection{Granulometric Surveys}

Granulometric analyses have been carried out from 2005-2008 following the American Society for Testing Materials 200 procedure (ASTM International-Standards Worldwide, 2006). Table 1 provides the characteristics of the soil samples taken in section 29 (see the location in Figure 7). The shoreline evolves rapidly due to the predominance of fine material, which is affected by ordinary wave action. The sharp slope at the bottom (almost 15\%), causes the loss of most of the material, triggering an erosion process that cannot be counteracted by the river sediment supply.

Table 1. Survey of 30.05.2005 at section 29 .

\begin{tabular}{cccccccc}
\hline Sample ( $\mathbf{N}^{\circ}$ ) & Depth $[\mathbf{m}]$ & $\mathbf{Y s}\left[\mathbf{k N} / \mathbf{m}^{\mathbf{3}}\right]$ & Gravel [\%] & Sand [\%] & Silt [\%] & Clay [\%] & d50 [mm] \\
\hline 2 & +1 & 25.70 & 52 & 48 & 0 & 0 & 3 \\
4 & 0 & 25.69 & 23 & 77 & 0 & 0 & 1.1 \\
6 & -2 & 25.59 & 58 & 42 & 0 & 0 & 7.4 \\
8 & -4 & 25.65 & 0 & 100 & 0 & 0 & 0.48 \\
\hline
\end{tabular}

\subsubsection{Wave Climate}

A hindcast analysis of the wave climate has been performed on the Tyrrhenian coast by using the coupled ECMWF-WAM wave model [87] validated by the data of the Ponza buoy, collected from 1 July 1989-31 December 1999, and by the Cetraro buoy, collected in 1999, (see EUROWAVES project, [88,89]). The Ponza buoy is a Wavec MKI directional wave meter located at $40^{\circ} 52^{\prime} 00^{\prime \prime} \mathrm{N}, 12^{\circ} 57^{\prime} 00^{\prime \prime} \mathrm{E}$; the Cetraro buoy is a Waverider directional wave meter located at $39^{\circ} 27^{\prime} 01^{\prime \prime} \mathrm{N}, 15^{\circ} 55^{\prime} 01^{\prime \prime} \mathrm{E}$ (Figure 4). Both the buoys are anchored at a depth of $100 \mathrm{~m}$. Figure 8 illustrates the offshore wave climate at Calabaia Beach.
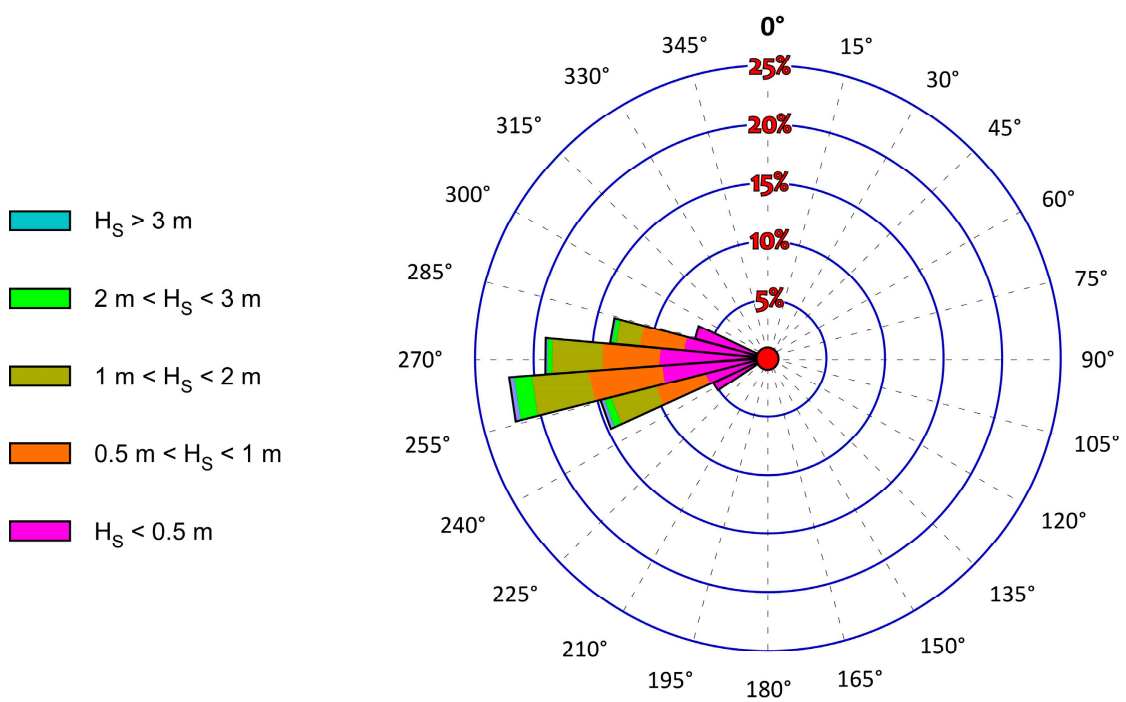

Figure 8. Offshore wave climate at Calabaia Beach, based on the EUROWAVES project hindcast.

\section{Coastal Management at Calabaia Beach: Experiences and Planning}

\subsection{Emergency Measures}

From the 1980s to the early 2000s several hard structures were built at Calabaia Beach after major storms, trying to limit flood risk for the population by using concrete blocks set a few meters seaward (Figure 9), affecting the landscape and the environment. 
(a)

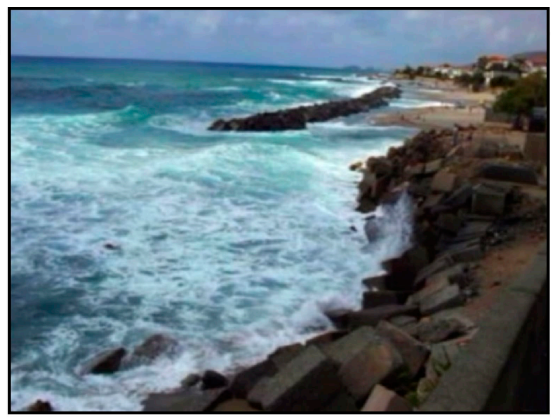

(c)

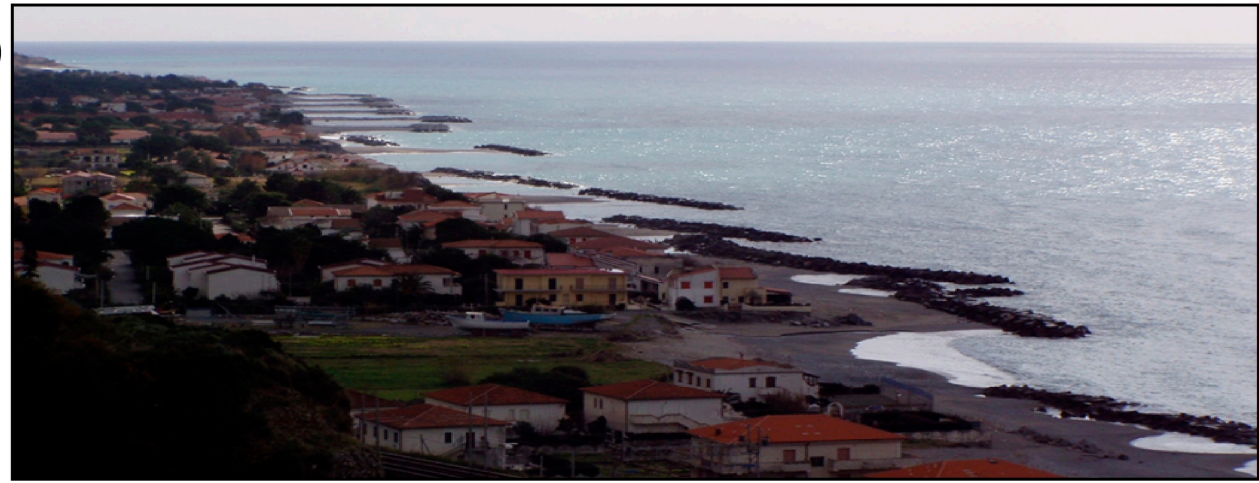

Figure 9. Calabaia Beach in 2002: (a) seaward view; (b) landward view; (c) an overview. (b)

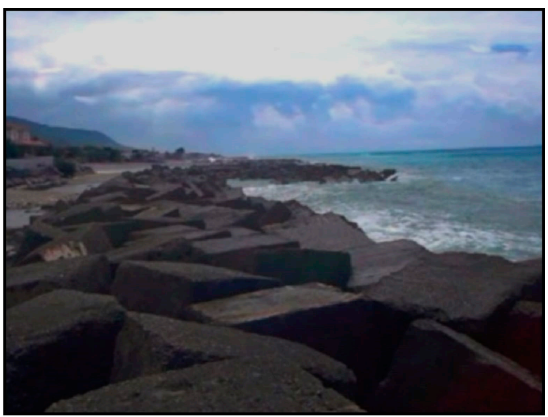

The rapid progression of the erosion process required a large use of hard defences, which, on the one hand, achieved the stabilization of the coastline, but, on the other hand, affected the environment, the landscape and the social value of the areas, since seawalls and breakwaters enhanced the erosion process beyond the structures and triggered a transversal sediment accretion, interfering with the natural growth of the beach $[61,62,77]$.

An example of the effect of the former interventions is provided by Figure 10, which refers to section 29 (see Figure 7) during the survey of 2005. The section, located near the urban settlement of Calabaia, shows a steep slope of the bottom. The sea defences protected only the coastal buildings, leaving the beach, located ahead, defenceless.

In this context, NBS would not have brought any benefit, constrained by the depth of the bottom.

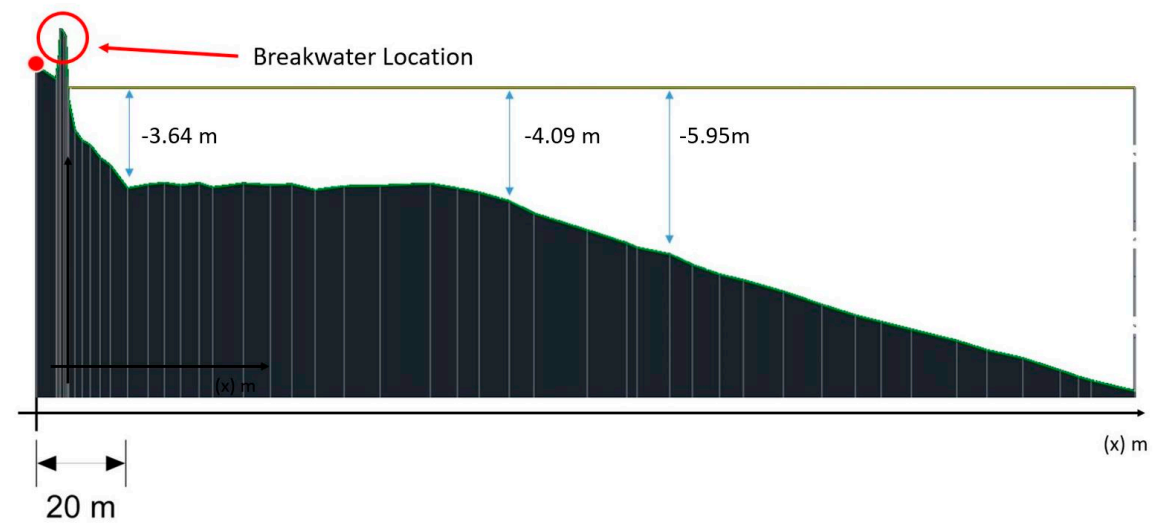

Figure 10. Survey of section 29 performed in May 2005. The red dot represents the location of the seafront buildings. 


\subsection{Perched Nourishment}

Once the threat to the assets had been counteracted, the awareness of the need for an environmental restoration arose, strongly supported by the needs of the local sea-economy (e.g., the move seaward option). Since the shoreline historically suffered erosion (Figure 6a), the optimum solution has been identified as a durable nourishment intervention supported by a submerged breakwater located at the toe of the refilling, allowing the dissipation of a large fraction of the wave energy.

In order to identify the optimum characteristics of the work, i.e., its location and the depth of the ridge, several simulations have been carried out supported by hydrodynamic [86] and physical models [86] evaluating the efficiency of the defence structure in a scaled-basin.

The hydrodynamic FLOW-3D model integrates the RANS (Reynolds Averaged Navier-Stokes equations) on a spatial grid through a Eulerian approach using the VOF (Volume of Fluid) technique to track the liquid surface [90]. The simulations were performed on a two-dimensional domain, to be aligned to the physical model, with and without the barrier and for different wave climates, focusing on changes in wave energy, wave setup and bottom friction produced by the submerged breakwater. Results show that the barrier increases the wave setup at the back (Figure 11a) and decreases bottom friction (Figure 11b).
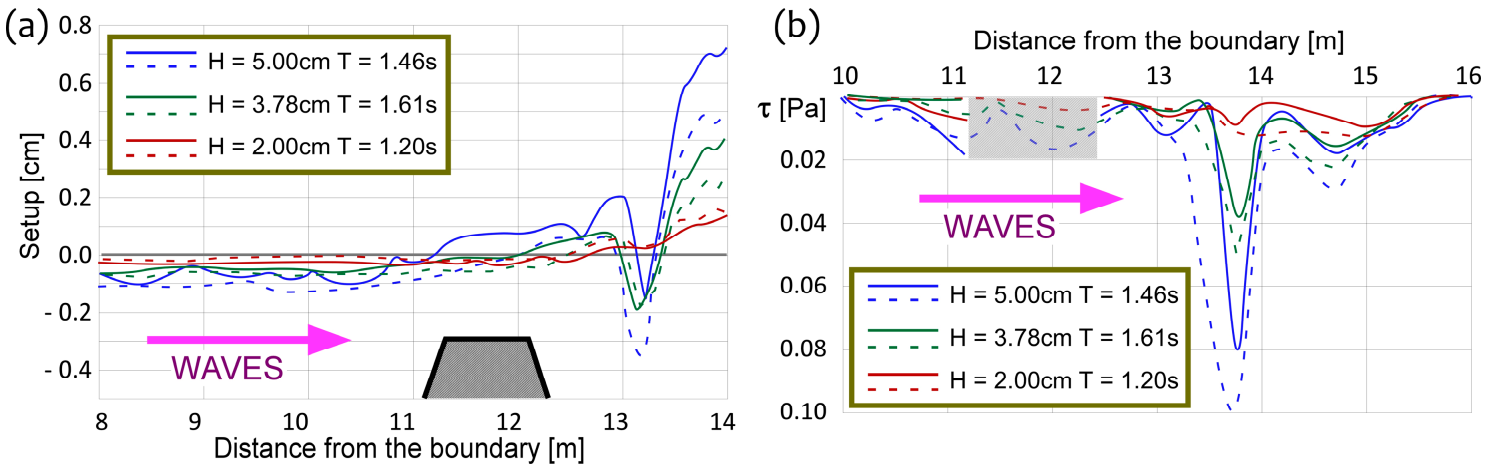

Figure 11. Effect of the submerged breakwater for different wave heights and periods: (a) wave setup; (b) bottom friction. Different lines represent the different incoming waves (thick lines with the breakwater; dashed lines without the breakwater). The effect of the breakwater is proportional to wave height [91].

A further set of scaled replicas were set up in a basin $18 \mathrm{~m}$ long, $3.6 \mathrm{~m}$ wide and $1.2 \mathrm{~m}$ deep (Figure 12), on the basis on the wave climate computed by means of the FLOW-3D model [91]. The basin is equipped with a wave generator, resistive probes, an acoustic Doppler profiler and a 3D laser scanner. The physical model allowed testing of the materials of the breakwater and of the nourishment by simulating the wave action. Results indicate that the submerged breakwater is stable, showing a wave reflection coefficient of 0.3 .

At the beginning of the 2000s, the large deterioration of the shoreline led the Calabria Region and the Province of Cosenza, supported by the CHL, to characterize the area in order to identify guidelines to protect urban settlements and to restore the environment $[48,85]$. These guidelines were drawn up into the Executive project for the defence and requalification of the coast in the Municipalities of Bonifati, Sangineto and Belvedere M.-Section from the north of Capo Bonifati to north of Capo Tirone, which includes the restoration of the Calabaia Beach by means of:

- a submerged breakwater located $250 \mathrm{~m}$ seaward, $2.5 \mathrm{~m}$ below the mean sea level and $700 \mathrm{~m}$ long. The structure consists of natural boulders and re-used concrete boulders taken from former emerged breakwaters;

- $\quad$ semi-submerged groynes made of natural boulders and re-used concrete boulders taken from former emerged breakwaters, connecting the heads of the submerged breakwater to the shoreline; 
- a beach nourishment using $600,000 \mathrm{~m}^{3}$ of quarried quartz sand with $\mathrm{d}_{50}=3 \mathrm{~mm}$, which is a material showing similar characteristics to the in-situ soil (Figure 13).

(a)

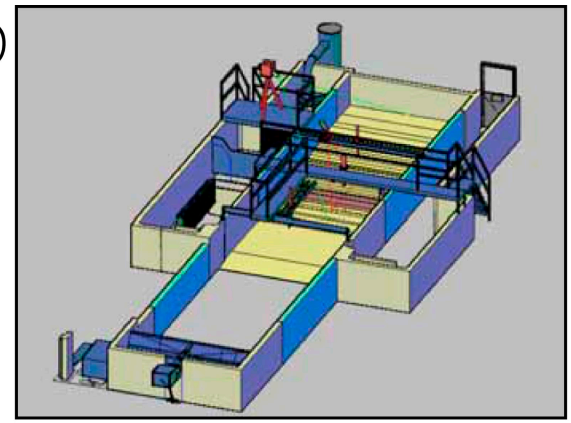

(c)

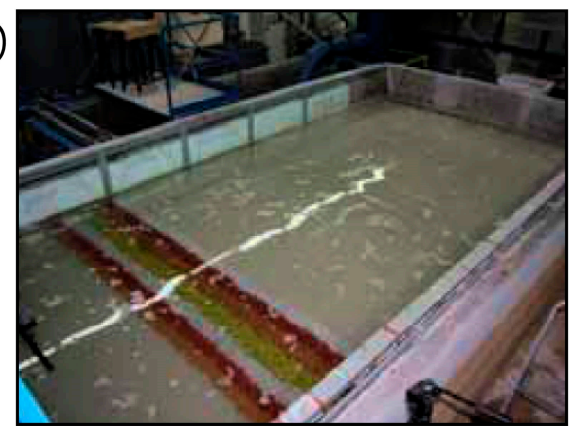

(b)

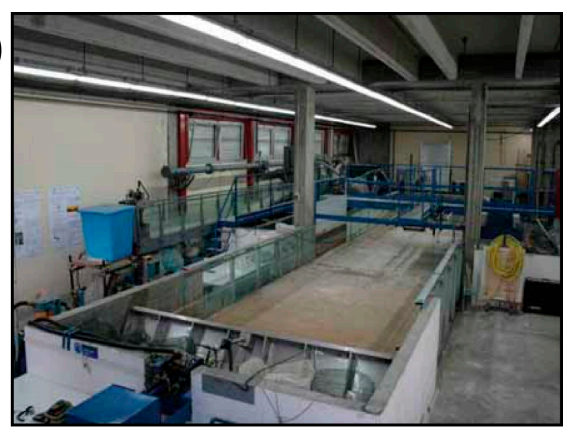

(d)

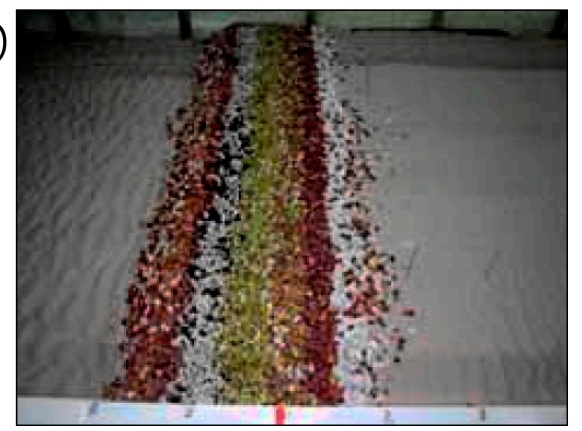

Figure 12. Basin used for the scaled-replicas: (a) 3D rendering of the laboratory channel; (b) foreground of the wave generator; (c) location of the coarse material before the experiment; (d) coarse material at the end of the experiment [91].

(a)

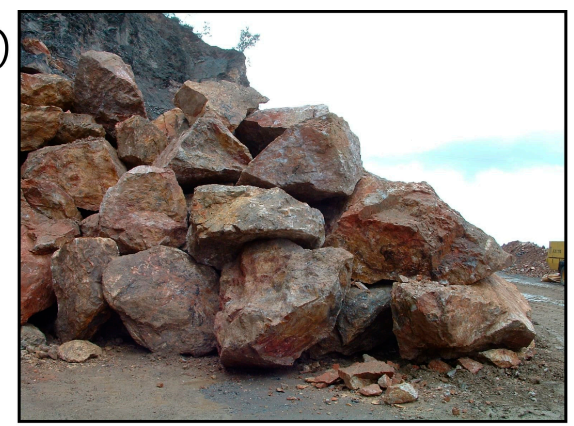

(c)

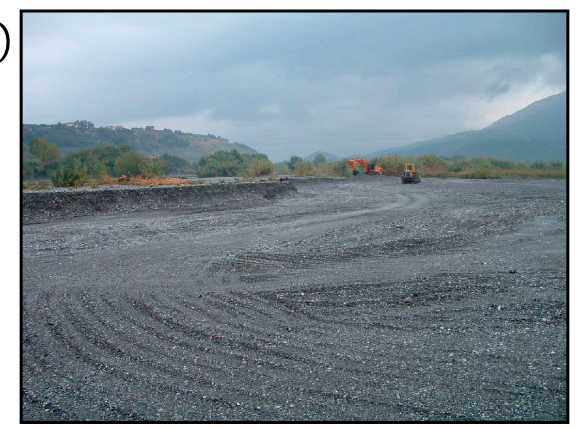

(b)

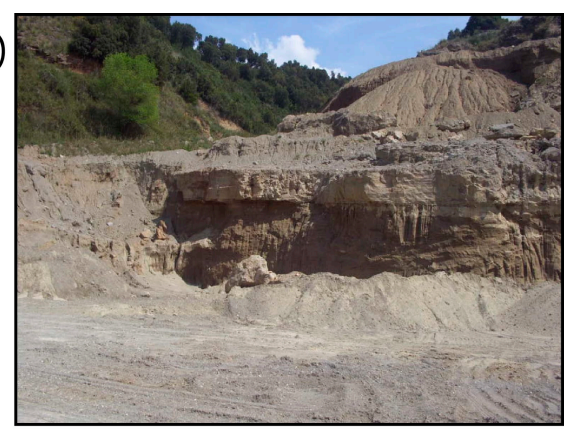

(d)

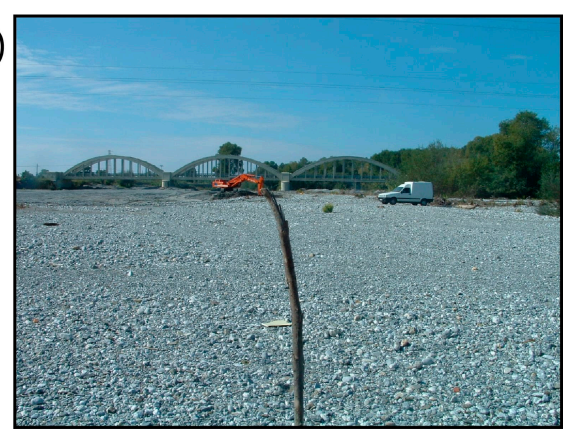

Figure 13. Materials used for the intervention: (a) quarry in the municipality of Cetraro (natural boulders); (b) quarry in the municipality of Orsomarso (nourishment sand); (c,d) fine material quarried from the Lao river. 
Figure 14 represents some stages of the works performed at Calabaia Beach in the early 2000s.

(a)

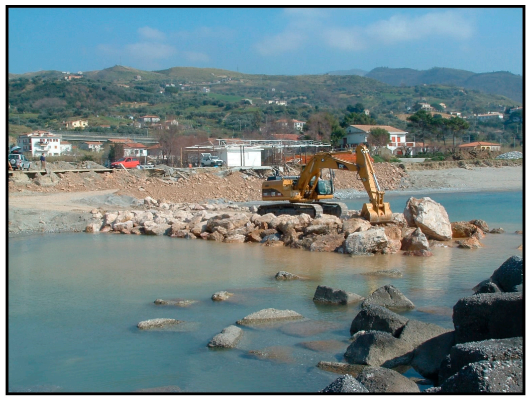

(c)

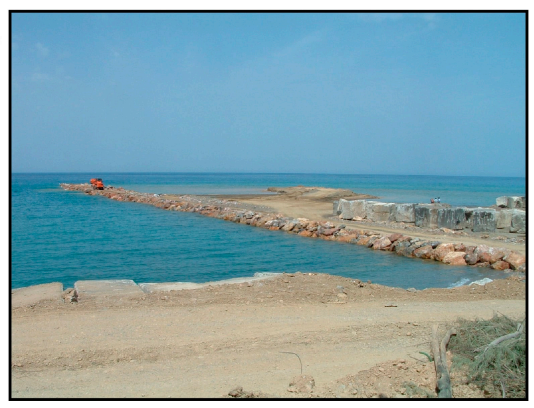

(b)

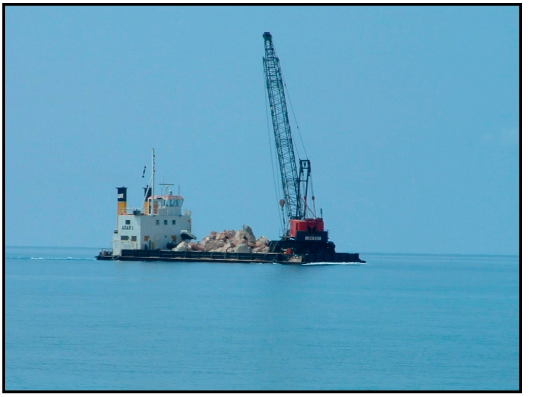

(d)

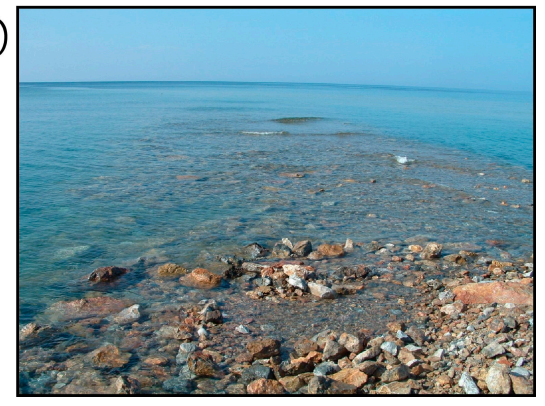

Figure 14. Works at Calabaia Beach: (a) construction of the emerged part of the groyne; (b) construction of the submerged breakwater using a pontoon; (c) construction of the submerged part of the groyne (the right shows the concrete boulders re-used from the former submerged breakwaters) and first nourishment of the beach; (d) view of the submerged part of the groyne after the removal of the track.

In the year 2006, the works were completed, allowing the adoption of further measures to restore the whole coastal area. (Figure 15).

(a)

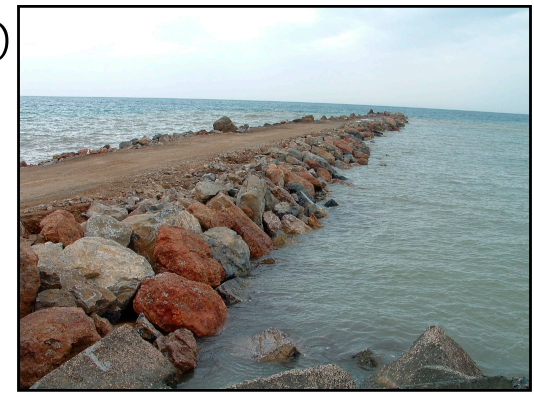

(b)

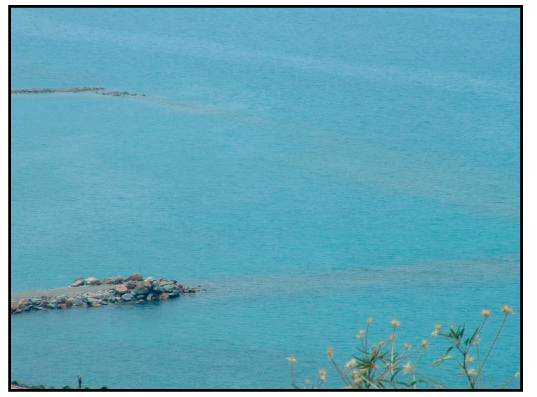

(c)

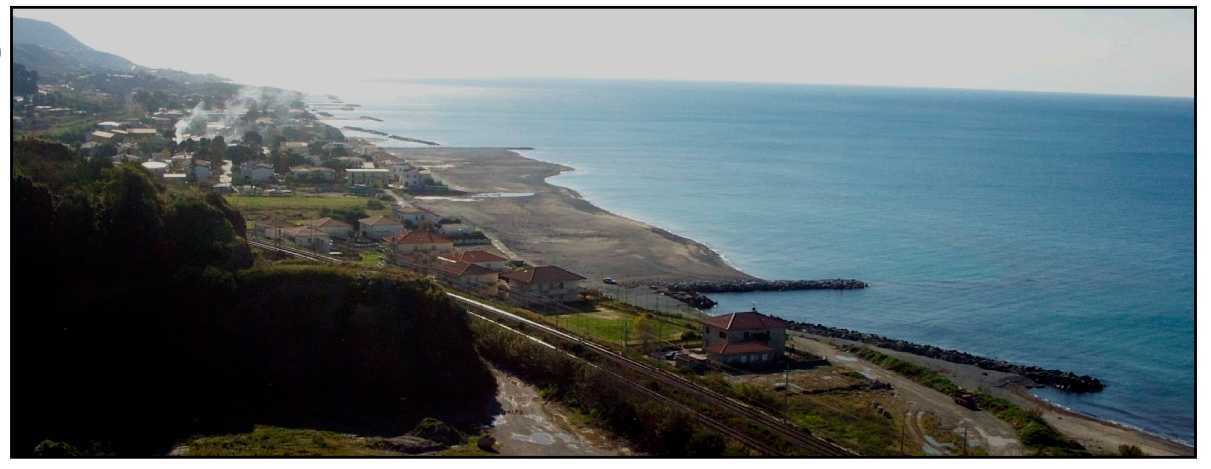

Figure 15. Calabaia Beach, works achieved (December 2006): (a) longitudinal view of the groyne; (b) boulders of the submerged breakwater; (c) plan view of the overall works. 
The intervention partly restored the environment and the landscape at Calabaia Beach (Figure 16).

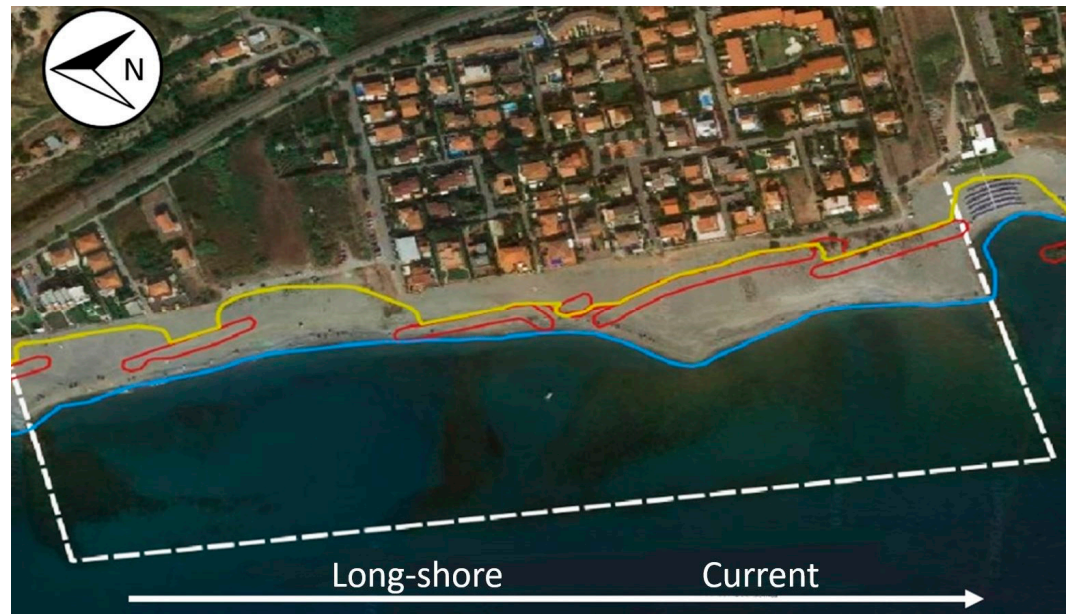

Figure 16. Calabaia Beach: effects of the intervention. Yellow line represents the original shoreline; blue line the current shoreline; red line the location of breakwaters in 2002. The white dotted line shows the boundary of the cell of the protected nourishment.

A further monitoring campaign $[86,90]$ proved the efficiency of the works in retaining the material in the cell, even if several significant storms occurred [91] (Figure 17).

The effectiveness of the perched nourishment has been evaluated by comparing satellite images taken in different periods (Figure 18). (a) illustrates the Calabaia Beach in September 2004, when the shoreline was close to the buildings. (b) shows the effect of the intervention ten years after the achievement of the works, estimating an increasing of the area of the beach of about $46,000 \mathrm{~m}^{2}$. Six years after (c) the beach has not changed, proving the achievement of the equilibrium profile of the beach.

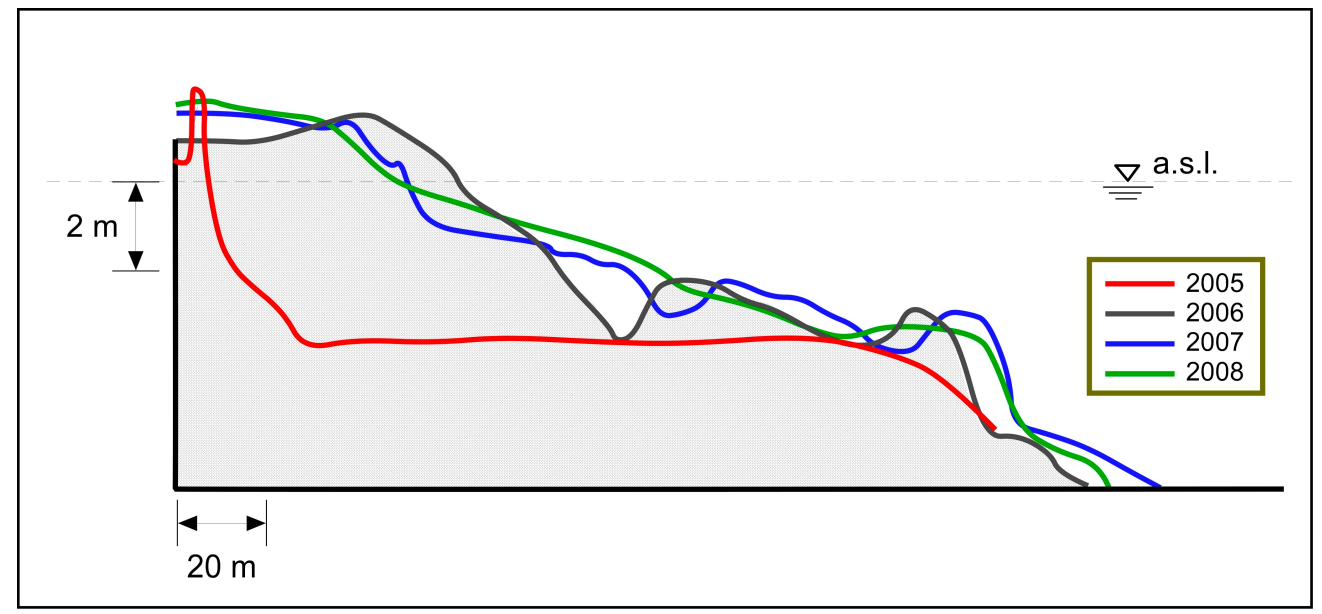

Figure 17. Bathymetric surveys of the cross-shore at Calabaia Beach from 2005 (before the end of the works) to 2008 [91]. 

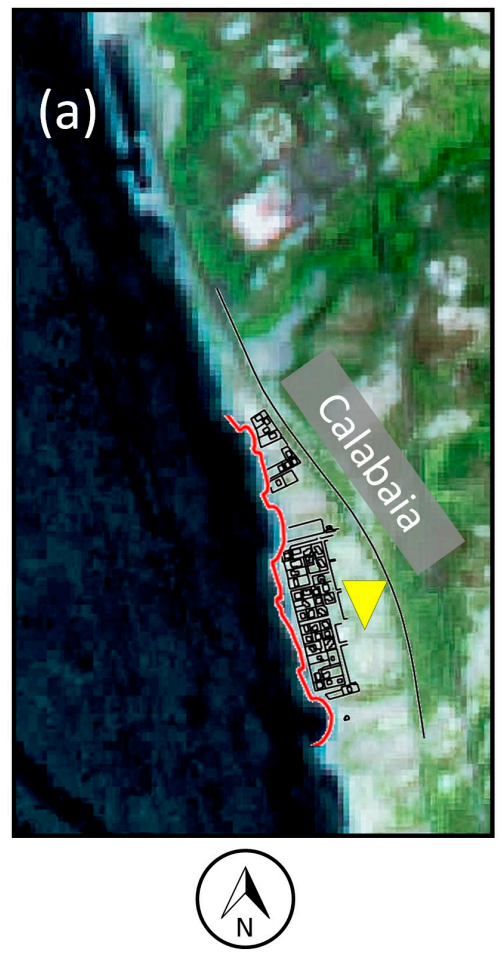
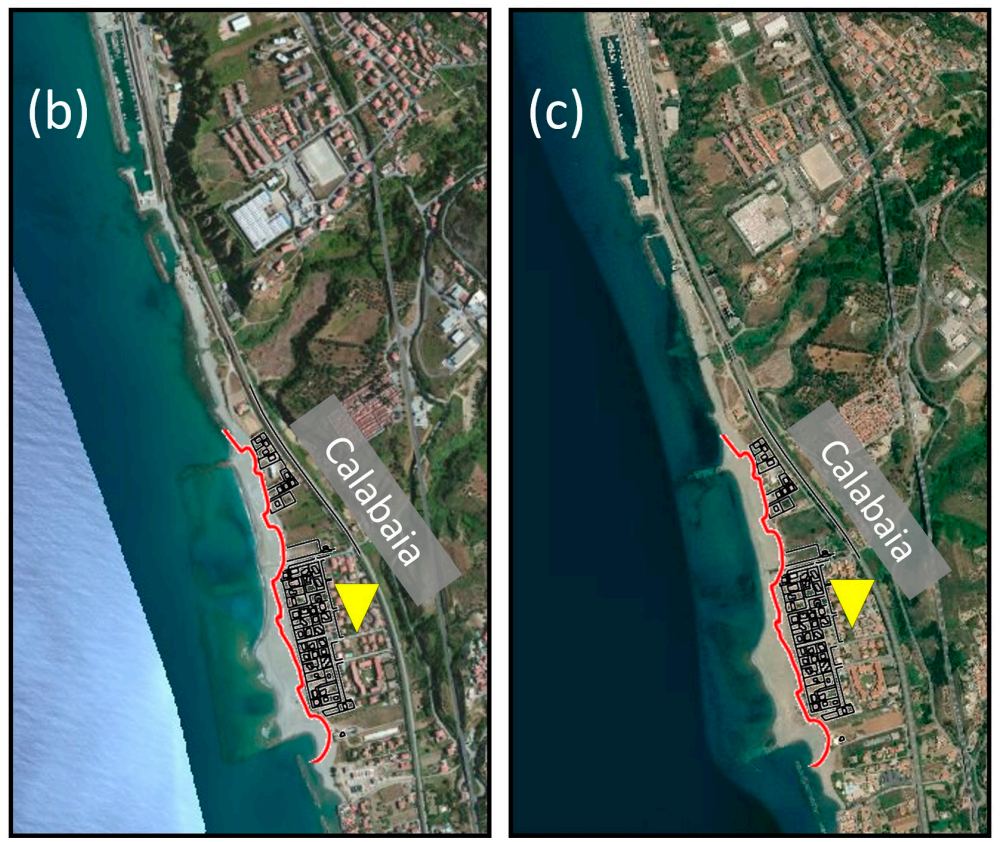

m 0

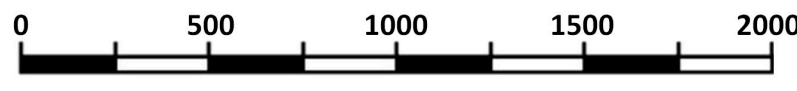

Figure 18. Calabaia Beach. (a) NASA satellite Aster L1T, res. 33 m, 14-09-2004; (b) ESRI Wayback Archive, res. 5 m, 20-02-2014; (c) ESRI Wayback Archive, res. 5 m, 29-04-2020. In red is the shoreline before the nourishment.

The protected nourishment proved to be an effective measure to protect the shoreline. Figure 19 illustrates the bed profile of section 29 (see Figure 7) three years after the nourishment, clearly highlighting a wide beach located between the shoreline and the seafront buildings, and an underwater mildly decreasing depth.

The solution of a perched beach supports both the protection of the shoreline and the use of the sea. As a footnote, we stress that the quality of the cliff-beach ecosystem can be further improved by means of NBS (e.g., Posidonia oceanica).

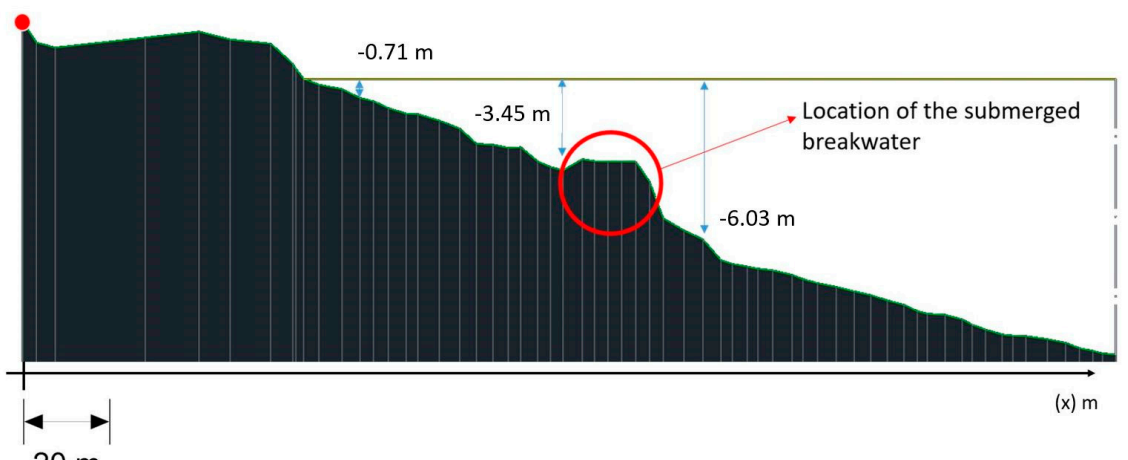

$20 \mathrm{~m}$

Figure 19. Survey of section 29 performed in May 2008. The slope of the bed is mild, with an almost linear deepening. Red point illustrates the location of the seafront buildings.

\subsection{NBS Example: The Further Use of Posidonia Oceanica at Calabaia Beach}

The restoration of Calabaia Beach began with the construction of a perched beach by removing the former rigid defence, aiming to increase the resilience of the environment by moving from a move seaward to a limited intervention option, on the basis that a rich and complex ecosystem 
faces ecological threats more successfully [92,93]. The actual target is to support the growth of Posidonia oceanica, a seagrass which is threatened worldwide by climate change and sea pollution. In particular, Posidonia oceanica meadows have been significantly reduced along the whole Southern Tyrrhenian coast [92,93], enhancing the local erosion process [94-97].

Studies focused on the rooting and the growth of the seagrass [98,99], showed that Posidonia oceanica thrives better in stable environments with coarse sands $[100,101]$ and is sensitive to seasonal variations of nutrients, with particular reference to nitrogen and phosphorus [102-105]. Posidonia oceanica reproduces through cuttings that can be easily transplanted into fertile environments [106]. The NBS proposed at Calabaia Beach consists of a Posidonia oceanica nourishment achieved by grafting seeds and cuttings on biodegradable films anchored to the seabed (Figure 3d), containing all the nutrients.

\subsubsection{Laboratory Experiments}

At the Chemical and Environmental Engineering Laboratory of the University of Calabria, the optimum bed-layer material for the growth of the Posidonia oceanica was investigate, which must be biodegradable and environmentally friendly, and capable of resisting wave action and being extruded in order to be anchored on the bottom to hold seeds and cuttings. The aggregating base of the film consists of poly-hydroxy-butyrate polymer in a percentage of between 10 and $50 \%$, which is biodegradable in about a year, ensuring good mechanical resistance until the plants have taken root. This is combined with 10-30\% of lignin, which provides excellent mechanical properties [107]. The nutrients are provided through a glutinous substance, which is an excellent plasticizer with good mechanical properties. The compound is finally enriched with other salts fundamental for the development of the plants.

Laboratory findings show good mechanical strength of the compound. Further tests will be carried out to identify the proportion of the components and the thickness of the film that entail the best mechanical properties.

\subsubsection{Sea Bottom Installation}

In recent years, several studies have evaluated the effect of the Posidonia oceanica on the inshore hydrodynamics of the area, addressing the wave attenuation on plant density and on submergence. Posidonia oceanica meadows reduce the inshore wave climate by means of the leaves and the leaf systems and retain the fraction of sediments covered by the vegetation [108-110].

The installation of the film on the seabed at Calabaia Beach will be performed at different depths by the divers of the Capo Tirone Marine Experimental Station, who are in charge of anchoring the film to the seabed by means of sand screws, designed in order to guarantee the adhesion of the film on the sandy substrate. The operation will be supported by a boat equipped with a reel system which locates the film as the boat advances along the barrier. Since currents and waves could interfere with the laying and anchoring operations and could affect the substrate, the season in which to begin the work has to be chosen accordingly. The planting of the cuttings and seeds will be performed by using both the native Posidonia oceanica meadows of Belvedere Marittimo and cuttings made in the laboratory.

Close to the protected site of Capo Tirone, Posidonia oceanica meadows actually reach a leaf height of about $60 \mathrm{~cm}$, with an approximate density of 400 to $500 \mathrm{stem} / \mathrm{m}^{2}$. Based on the bathymetry of the area, the target is to plant four strips of Posidonia oceanica located parallel to the shoreline, $20 \mathrm{~m}$ wide each. In order to reduce the wave energy from $2.5 \mathrm{~m}$ sea depth, the optimum solution is a high-density strip of seeds and cuttings within the nourishment area located close to the barrier. The submergence ratio between the depth of the seabed and the height of the leaf should improve the damping of waves of a significant height $>2 \mathrm{~m}[108,109]$.

Seaward of the breakwater, planting will start at $6.5 \mathrm{~m}$ sea depth and ends at about $8 \mathrm{~m}$ sea depth, covering an area of about $60 \times 700 \mathrm{~m}^{2}$ through four strips of Posidonia oceanica characterized by different densities, ranging from $400 \mathrm{stem} / \mathrm{m}^{2}$ close to the barrier to lower values seaward (Figures 20 and 21). The second high-density area located close to the breakwater does not significantly support wave 
reduction, because the submergence ratio is too small. The purpose of this layer is to increase the durability of the work, by reducing the effects of waves and currents, with particular reference to the scouring effect at the toe. The two low density layers do not have a specific hydrodynamic purpose, mainly supporting the local habitat and the monitoring of the plants.

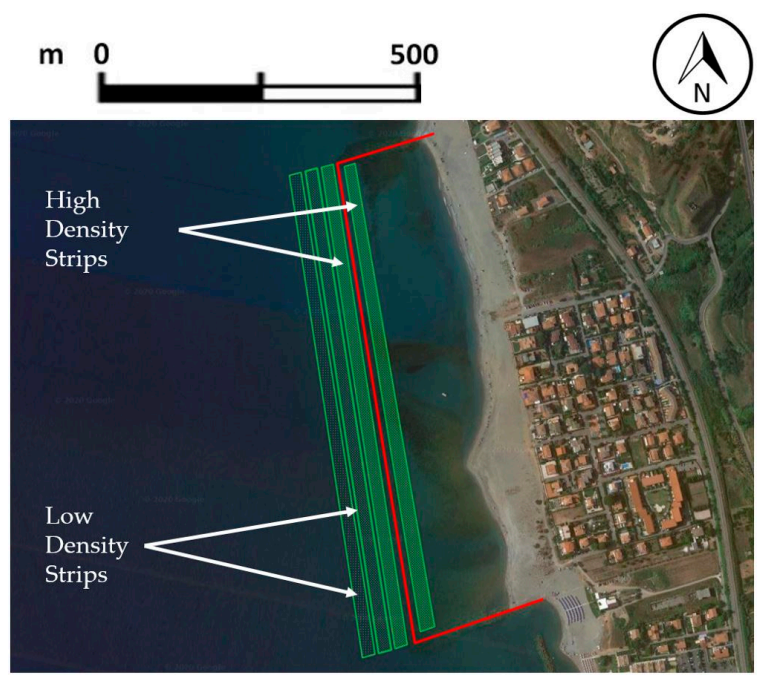

Figure 20. Location of the four strips of Posidonia oceanica proposed in the area of Calabaia Beach.

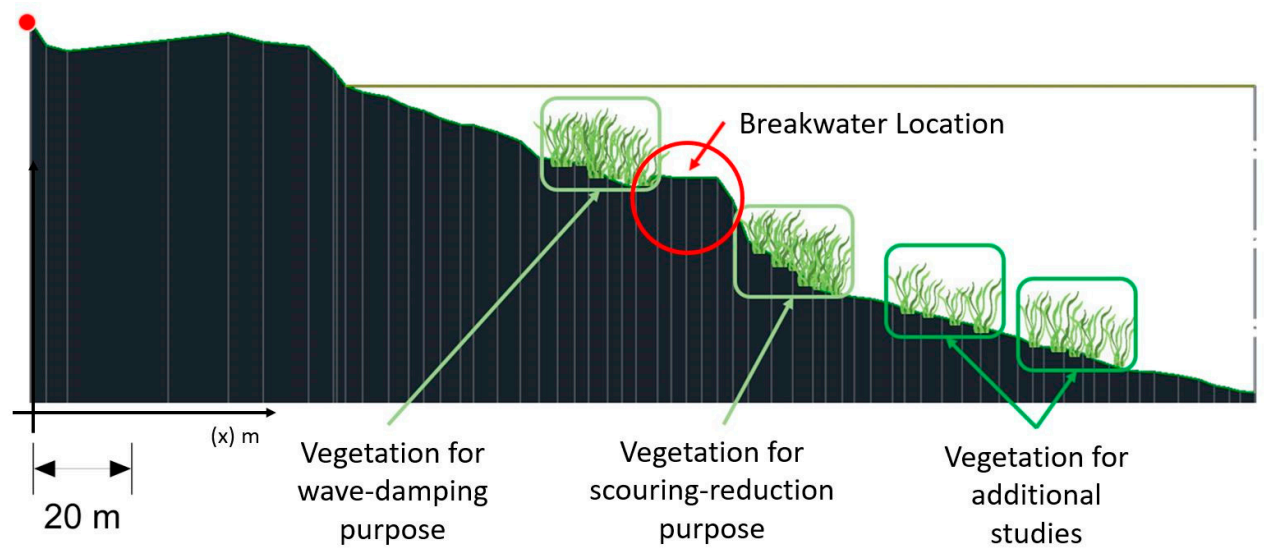

Figure 21. Example of implantation of Posidonia oceanica in section 29.

\subsubsection{Monitoring Campaigns}

The intervention requires a monitoring campaign performed every fifteen days of the first quarter, aiming to evaluate the percentage of germination of the seeds, the foliar and radical development of the cuttings, the presence of benthic macroinvertebrates in the matte substrate, and the anomalies of the film.

The growth of the Posidonia oceanica will be further supervised through photographic inspections carried out by means of the AUV Tirone I (Figure 22a), which can also monitor the chemical status of the water by means of a multiparameter scope, evaluating the health of the ecosystem. In particular, the data will be compared to the database belonging the protected area of Capo Tirone (Figure 22b,c), in order to identify possible threats to the plants and to monitor the proliferation of competitor species, such as the allochthonous algae of the Caulerpa family, which have invaded the ecological niche of Posidonia in many areas of the Mediterranean Sea [111,112].

In addition, the sedimentological budget of the beach will be monitored in order to address the presence of Posidonia oceanica and its effects on the retention of the sediments on the bottom. Periodic bathymetric surveys will be performed by means of a MultiBeam sonar to detect any changes in beach 
morphology. Finally, a set of simulations will be carried out by means of a mathematical model with the aim of quantifying the effects of the Posidonia oceanica on wave damping and on sediment budget.

(a)

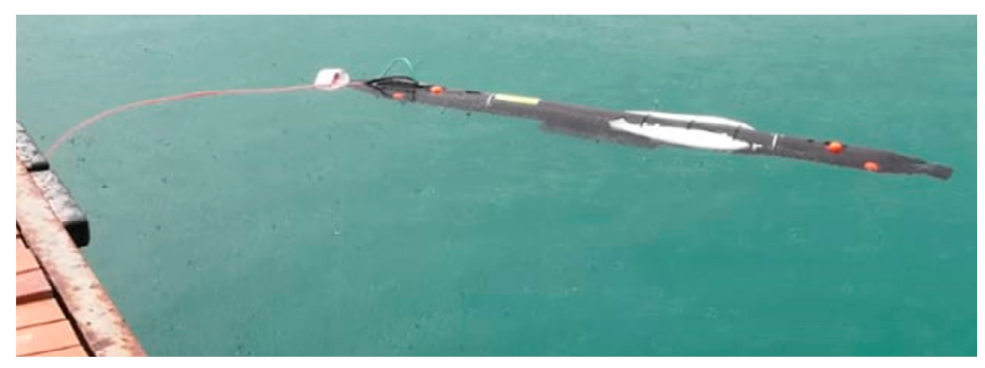

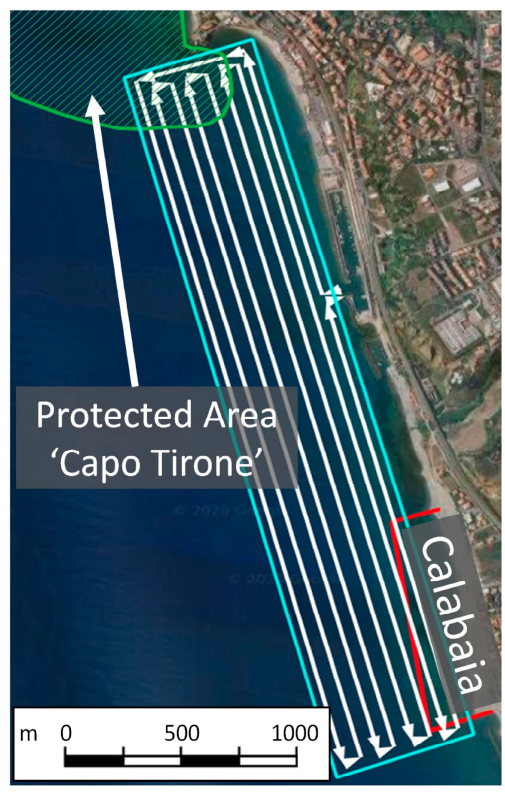

(b)

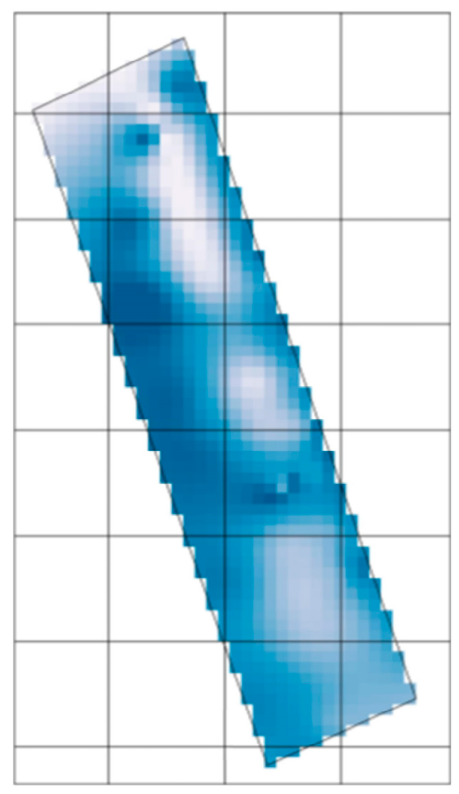

(c)

Figure 22. (a) Autonomous Underwater Vehicle (AUV) Tirone I in ROV navigation mode; (b) monitored area by means of the AUV. Green line delimits the protected area of Capo Tirone; red line indicates the location of the submerged breakwater; white line the track prescribed to the AUV for autonomous navigation. (c) illustrates an example based on the data collected by the AUV in the monitoring area (b), showing the concentration of dissolved oxygen. Darker colours represent higher values of dissolved oxygen.

\section{Discussion and Conclusions}

Erosion process produces long-term effects on coastal environments, threating urban settlements and leading to the building of emergency structures that often affect the landscape and the ecosystem, which requires to be further restored by means of more expensive measures. In this context, recent maritime policies promote environmentally friendly and sustainable measures aimed at protecting both buildings and natural resources. Nature based solutions are often preferred to former approaches that did not consider the needs of the environment and the ecosystem. However, certain nature-based interventions aimed at restoring the coastal ecosystems failed in their purposes, mainly due to an incorrect estimation of the bio-geomorphic feedbacks that characterize the ecosystem.

This document illustrates the time-dependent approach performed at Calabaia Beach, an area that has been subjected to several sea-defence interventions, shifting from a hold the line method toward the move seaward and limited intervention measures, since the do nothing solution has proved to be ineffective due to the erosion processes that affect the area. In the past century, many hard structures 
successfully protected the seafront buildings located at Calabaia Beach from the damages produced by major swells, allowing the touristic use of the sea, but affecting the environment. At the beginning of the present century, the coast has been partly restored through beach nourishment supported by submerged breakwaters and groynes, built using the material taken from the former structures. The intervention proved to be effective, protecting the coastal settlements by reducing wave energy, keeping sand in the erosion cells and restoring the whole ecosystem. Further measures consist in planting Posidonia oceanica meadows beyond the groynes, which serve as lung, larder, nursery of the sea and as a shelter where several marine species can thrive.

The case study of Calabaia Beach is a worthwhile example of the implementation of a time-dependent strategy in counteracting coastal erosion and in restoring the environment, in accord with the most recent EU directives. We speculate that this methodology could be successfully applied to other case studies when it is required to balance flooding protection with economic interests and the safeguarding of the coastal ecosystem. However, any restoration measure has to be evaluated on the basis of the specific nature of the area, promoting, if possible, long-term planning that first focuses on the natural action of the beach on the retaining of the material, and then on the restoration of the environment and the ecosystem.

Author Contributions: Conceptualization, M.M.; methodology, M.M., R.A.M. and S.S.; software, S.S.; validation, M.M., and R.A.M.; formal analysis, M.M.; investigation, M.M., S.S.; resources, M.M.; data curation, M.M. and S.S.; writing-original draft preparation, M.M., and S.S.; writing-review and editing, M.M., R.A.M. and S.S.; visualization, R.A.M.; supervision, M.M.; project administration, M.M.; funding acquisition, M.M. All authors have read and agreed to the published version of the manuscript.

Funding: This research was funded by Governo Italiano, Piano di interventi infrastrutturali di emergenza in Calabria-eventi alluvionali settembre 2000, Ordinanza di Protezione Civile n ${ }^{\circ} 3081 / 2000$, by Regione Calabria, Progetto Integrato Strategico-Rete Ecologica Regionale, POR Calabria-Asse I-Misura 1.10, Convenzione ${ }^{\circ} 1562$, and by Provincia di Cosenza, Progetto esecutivo per la difesa e riqualificazione del litorale nei Comuni di Bonifati, Sangineto e Belvedere M.-Tratto da nord Capo Bonifati a nord Capo Tirone, PEG-Bilancio 2004.

Acknowledgments: The authors thank the participants in this study for their time and useful insights. We also thank the support by the Province of Cosenza for the technical documentation provided.

Conflicts of Interest: The authors declare no conflict of interest.

\section{References}

1. Patterson, M.; Glavovic, B. From frontier economics to an ecological economics of the oceans and coasts. Sustain. Sci. 2013, 8, 11-24. [CrossRef]

2. Folke, C.; Biggs, R.; Norström, A.V.; Reyers, B.; Rockström, J. Social-ecological resilience and sustainability. Ecol. Soc. 2016, 21, 41. [CrossRef]

3. Turner, R.K. Integrating natural and socio-economic science in coastal management. J. Mar. Syst. 2000, 25, 447-460. [CrossRef]

4. Leslie, H.M.; Basurto, X.; Nenadovic, M.; Sievanen, L.; Cavanaugh, K.C.; Cota-Nieto, J.J.; Erisman, B.E.; Finkbeiner, E.; Hinojosa-Arango, G.; Moreno-Báez, M.; et al. Operationalizing the social-ecological systems framework to assess sustainability. Proc. Natl. Acad. Sci. USA 2015, 112, 5979-5984. [CrossRef]

5. Ye, G.; Chou, L.M.; Yang, S.; Wu, J.; Liu, P.; Jin, C. Is integrated coastal management an effective framework for promoting coastal sustainability in China's coastal cities? Mar. Policy 2015, 56, 48-55. [CrossRef]

6. Mele, B.H.; Russo, L.; D'Alelio, D. Combining marine ecology and economy to roadmap the integrated coastal management: A systematic literature review. Sustainability 2019, 11, 4393. [CrossRef]

7. Fedorov, G.M.; Kuznetsova, T.Y.; Razumovskii, V.M. How the proximity of the sea affects development of economy and the settlement pattern in Kaliningrad oblast. Reg. Res. Russ. 2017, 7, 352-362. [CrossRef]

8. Ertör, I.; Hadjimichael, M. Editorial: Blue degrowth and the politics of the sea: Rethinking the blue economy. Sustain. Sci. 2020, 15, 1-10. [CrossRef]

9. Capobianco, M.; De Vriend, H.J.; Nicholls, R.J.; Stive, M.J.F. Coastal Area Impact and Vulnerability Assessment: The Point of View of a Morphodynamic Modeller. J. Coast. Res. 1999, 15, 701-716.

10. De Zolt, S.; Lionello, P.; Nuhu, A.; Tomasin, A. The disastrous storm of 4 November 1966 on Italy. Nat. Hazards Earth Syst. Sci. 2006, 6, 861-879. [CrossRef] 
11. Gedan, K.B.; Silliman, B.R.; Bertness, M.D. Centuries of human-driven change in saltmarsh ecosystems. Annu. Rev. Mar. Sci. 2009, 1, 117-141.

12. Liquete, C.; Zulian, G.; Delgado, I.; Stips, A.; Maes, J. Assessment of coastal protection as an ecosystem service in Europe. Ecol. Indic. 2013, 30, 205-217. [CrossRef]

13. Mel, R.; Viero, D.P.; Carniello, L.; Defina, A.; D'Alpaos, L. Simplified methods for real-time prediction of storm surge uncertainty: The city of Venice case study. Adv. Water Resour. 2014, 71, 177-185.

14. Mel, R.; Lionello, P. Storm surge ensemble prediction for the city of Venice. Weather Forecast. 2014, 29, 1044-1057.

15. Mel, R.; Lionello, P. Verification of an ensemble prediction system for storm surge forecast in the Adriatic Sea. Ocean Dyn. 2014, 64, 1803-1814.

16. Mel, R.; Lionello, P. Probabilistic dressing of a storm surge prediction in the Adriatic Sea. Adv. Meteorol. 2016, 2016, 3764519. [CrossRef]

17. Marcos, M.; Tsimplis, M. Forcing of coastal sea level rise patterns in the North Atlantic and the Mediterranean Sea. Geophys. Res. Lett. 2007, 34, L01604. [CrossRef]

18. Prather, M.; Flato, G.; Friedlingstein, P.; Jones, C.; Lamarque, J.-F.; Liao, H.; Rasch, P. Annex II: Climate System Scenario Tables. In Climate Change 2013: The Physical Science Basis. Contribution of Working Group I to the Fifth Assessment Report of the Intergovernmental Panel on Climate Change; Stocker, T.F., Qin, D., Plattner, G.-K., Tignor, M., Allen, S.K., Boschung, J., Nauels, A., Xia, Y., Bex, V., Midgley, P.M., Eds.; Cambridge University Press: Cambridge, UK; New York, NY, USA, 2013.

19. Mel, R.; Sterl, A.; Lionello, P. High resolution climate projection of storm surge at the Venetian coast. Nat. Hazards Earth Syst. Sci. 2013, 13, 1135-1142. [CrossRef]

20. Scarascia, L.; Lionello, P. Global and regional factors contributing to the past and future sea level rise in the northern Adriatic Sea. Glob. Planet. Chang. 2013, 106, 51-63. [CrossRef]

21. Pranzini, E.; Wetzel, A.; Williams, A. Aspects of coastal erosion and protection in Europe. J. Coast. Conserv. 2015, 19, 445-459. [CrossRef]

22. Bendoni, M.; Mel, R.; Solari, L.; Lanzoni, S.; Francalanci, S.; Oumeraci, H. Insights into lateral marsh retreat mechanism through localized field measurements. Water Resour. Res. 2016, 52, 1446-1464. [CrossRef]

23. Mel, R.; Carniello, L.; D'Alpaos, L. Addressing the effect of the Mo.S.E. barriers closure on wind setup within the Venice lagoon. Estuar. Coast. Shelf Sci. 2019, 225, 106249. [CrossRef]

24. Finotello, A.; Marani, M.; Carniello, L.; Pivato, M.; Roner, M.; Tommasini, L.; D'alpaos, A. Control of wind-wave power on morphological shape of salt marsh margins. Water Sci. Eng. 2020, 13, 45-56. [CrossRef]

25. Nuzula, N.I.; Armono, H.D.; Rosyid, D.M. The Impact of Coastal Tourism Activities on Water Quality at Baluran National Park. IPTEK J. Technol. Sci. 2017, 28, 59-62.

26. Huang, W. The Influence of Cruise Tourism Dining Waste on the Process of Self-recovery of Natural Ecological Environment. Ekoloji 2019, 28, 49-54.

27. Lamine, I.; Alla, A.A.; Bourouache, M.; Moukrim, A. Monitoring of physicochemical and microbiological quality of Taghazout seawater (Southwest of Morocco): Impact of the new tourist resort "Taghazout bay". J. Ecol. Eng. 2019, 20, 79-89. [CrossRef]

28. U.S.A.C.E (U.S. Army Corps of Engineers). Coastal Engineering Manual (CEM); U.S. Army Engineer Research and Development Center (ERDC): Vicksburg, MS, USA, 2003.

29. Coelho, C.; Narra, P.; Marinho, B.; Lima, M. Coastal Management Software to Support the Decision-Makers to Mitigate Coastal Erosion. J. Mar. Sci. Eng. 2020, 8, 37. [CrossRef]

30. Post, J.C.; Lundin, C.G. Guidelines for Integrated Coastal Zone Management; The World Bank: Washington, DC, USA, 1996; Volume 9, ISBN 0821337351.

31. EUROSION. Living with Coastal Erosion in Europe: Sediment and Space for Sustainability—Part I-Major Findings and Policy Recommendations of the EUROSION Project. 2004. Available online: http://www. eurosion.org/reports-online/part1.pdf (accessed on 18 September 2020).

32. OECD. The Ocean Economy in 2030; OECD Publishing: Paris, France, 2016.

33. Board, M. Beach Nourishment and Protection; Press, N.A., Ed.; National Academies Press: Washington, DC, USA, 1995; Volume 63.

34. Luijendijk, A.; Hagenaars, G.; Ranasinghe, R.; Baart, F.; Donchyts, G.; Aarninkhof, S. The State of the World's Beaches. Sci. Rep. 2018, 8, 6641. [CrossRef] 
35. Sutherland, J. Guidelines on Beach Monitoring for Coastal Erosion in Concepts and Science for Coastal Erosion Management (Conscience) Project. Deliverable D15. 2010. Available online: http://www.conscienceeu.net/documents/deliverable15-guidelines-on-beach-monitoring-for-coastal-erosion.pdf (accessed on 18 September 2020).

36. Loinenak, F.A.; Hartoko, A.; Muskananfola, M.R. Mapping of coastal vulnerability using the coastal vulnerability index and geographic information system. Int. J. Technol. 2015, 6, 819-827. [CrossRef]

37. Sinay, L.; Carter, R.W. Climate Change Adaptation Options for Coastal Communities and Local Governments. Climate 2020, 8, 7. [CrossRef]

38. Cantasano, N.; Pellicone, G.; Ietto, F. Integrated coastal zone management in Italy: A gap between science and policy. J. Coast. Conserv. 2017, 21, 317-325. [CrossRef]

39. Antonioli, F.; Anzidei, M.; Amorosi, A.; Presti, V.L.; Mastronuzzi, G.; Deiana, G.; De Falco, G.; Fontana, A.; Fontolan, G.; Lisco, S.; et al. Sea-level rise and potential drowning of the Italian coastal plains: Flooding risk scenarios for 2100. Quat. Sci. Rev. 2017, 158, 29-43. [CrossRef]

40. Martin, D.; Bertasi, F.; Colangelo, M.A.; de Vries, M.; Frost, M.; Hawkins, S.J.; Macpherson, E.; Moschella, P.S.; Satta, M.P.; Thompson, R.C.; et al. Ecological impact of coastal defence structures on sediment and mobile fauna: Evaluating and forecasting consequences of unavoidable modifications of native habitats. Coast. Eng. 2005, 52, 1027-1051. [CrossRef]

41. Martins, G.M.; Amaral, A.F.; Wallenstein, F.M.; Neto, A.I. Influence of a breakwater on nearby rocky intertidal community structure. Mar. Environ. Res. 2009, 67, 237-245. [CrossRef]

42. Bulleri, F.; Chapman, M.G. The introduction of coastal infrastructure as a driver of change in marine environments. J. Appl. Ecol. 2010, 47, 26-35. [CrossRef]

43. Ružić, I.; Jovančević, S.D.; Benac, Č.; Krvavica, N. Assessment of the coastal vulnerability index in an area of complex geological conditions on the krk island, northeast adriatic sea. Geosciences 2019, 9, 219. [CrossRef]

44. Maiolo, M.; Pantusa, D. Sustainable Water Management Index, SWaM_Index. Cogent Eng. 2019, 6, 1603817. [CrossRef]

45. Speybroeck, J.; Bonte, D.; Courtens, W.; Gheskiere, T.; Grootaert, P.; Maelfait, J.P.; Mathys, M.; Provoost, S.; Sabbe, K.; Stienen, E.W.M.; et al. Beach nourishment: An ecologically sound coastal defence alternative? A review. Aquat. Conserv. Mar. Freshw. Ecosyst. 2006, 16, 419-435. [CrossRef]

46. Rakocinski, C.F.; Heard, R.W.; LeCroy, S.E.; McLelland, J.A.; Simons, T. Responses by macrobenthic assemblages to extensive beach restoration at Perdido Key, Florida, U.S.A. J. Coast. Res. 1996, 12, 326-353.

47. Guidetti, P.; Fabiano, M. The use of lepidochronology to assess the impact of terrigenous discharges on the primary leaf production of the Mediterranean seagrass Posidonia oceanica. Mar. Pollut. Bull. 2000, 40, 449-453. [CrossRef]

48. Warnken, J.; Mosadeghi, R. Challenges of implementing integrated coastal zone management into local planning policies, a case study of Queensland, Australia. Mar. Policy 2018, 91, 75-84.

49. Maiolo, M.; Mel, R.; Sinopoli, S. A Simplified Method for an Evaluation of the Effect of Submerged Breakwaters on Wave Damping: The Case Study of Calabaia Beach. J. Mar. Sci. Eng. 2020, 8, 510. [CrossRef]

50. Maiolo, M.; Versace, P.; Natale, L.; Irish, J.; Pope, J.; Frega, F. A comprehensive study of the tyrrhenian shoreline of the Province of Cosenza. In Proceedings of the Giornate Italiane di Ingegneria Costiera V Edizione (AIPCN 2000), Reggio Calabria, Italy, 11-13 October 2000.

51. Bossolasco, M. L'Erosione del litorale di Belvedere Marittimo. Geofis. Pura Appl. 1939, 1, 47-51.

52. Ruíz, J.M.; Marín, A.; Calvo, J.F.; Ramírez-Diaz, L. Interactions between a floodway and coastal constructions in Aguila bay (Southeastern Spain). Ocean Coast. Manag. 1993, 19, 241-262.

53. Ruiz, J.M.; Romero, J. Effects of disturbances caused by coastal constructions on spatial structure, growth dynamics and photosynthesis of the seagrass Posidonia oceanica. Mar. Pollut. Bull. 2003, 46, 1523-1533.

54. Bellotti, P.; Caputo, C.; Davoli, L.; Evangelista, S.; Pugliese, F. Coastal protections in Tyrrhenian Calabria (Italy): Morphological and sedimentological feedback on the vulnerable area of belvedere Marittimo. Geogr. Fis. Din. Quat. 2009, 32, 3-14.

55. De Falco, G.; Molinaroli, E.; Baroli, M.; Bellacicco, S. Grain size and compositional trends of sediments from Posidonia oceanica meadows to beach shore, Sardinia, western Mediterranean. Estuar. Coast. Shelf Sci. 2003, 58, 299-309. 
56. Corenblit, D.; Tabacchi, E.; Steiger, J.; Gurnell, A.M. Reciprocal interactions and adjustments between fluvial landforms and vegetation dynamics in river corridors: A review of complementary approaches. Earth Sci. Rev. 2007, 84, 56-86.

57. Temmerman, S.; Meire, P.; Bouma, T.J.; Herman, P.M.J.; Ysebaert, T.; De Vriend, H.J. Ecosystem-based coastal defence in the face of global change. Nature 2013, 504, 79-83.

58. Arkema, K.K.; Griffin, R.; Maldonado, S.; Silver, J.; Suckale, J.; Guerry, A.D. Linking social, ecological, and physical science to advance natural and nature-based protection for coastal communities. Ann. N. Y. Acad. Sci. 2017, 1399, 5-26.

59. Menéndez, P.; Losada, I.J.; Torres-Ortega, S.; Narayan, S.; Beck, M.W. The Global Flood Protection Benefits of Mangroves. Sci. Rep. 2020, 10,1-11. [CrossRef] [PubMed]

60. van Rijn, L.C. Principles of Sedimentation and Erosion Engineering in Rivers, Estuaries and Coastal Seas Including Mathematical Modelling Package; Aqua Publications: Amsterdam, The Netherlands, 2005; ISBN 9080035661.

61. Yasso, W.E. Plan Geometry of Headland-Bay Beaches. J. Geol. 1965, 73, 702-714. [CrossRef]

62. Silvester, R. Natural headland control of beaches. Cont. Shelf Res. 1985, 4, 581-596. [CrossRef]

63. Houston, J.R. Beach-fill design. In Advances in Coastal and Ocean Engineering; Philip, L., Liu, F., Eds.; World Scientific: Singapore, 1996; pp. 199-229.

64. Dean, R.G. Equilibrium beach profiles: Characteristics and applications. J. Coast. Res. 1991, 7, 53-84.

65. Kriebel, D.L.; Dean, R.G. Numerical Simulation of Time-Dependent Beach and Dune Erosion. Coast. Eng. 1985, 9, 221-245. [CrossRef]

66. González, M.; Medina, R.; Losada, M.A. Equilibrium beach profile model for perched beaches. Coast. Eng. 1999, 36, 343-357. [CrossRef]

67. Sorensen, R.M.; Beil, N.J. Perched beach profile response to wave action. In Proceedings of the 21st International Conference on Coastal Engineering, Malaga, Spain, 20-25 June 1988; pp. 1482-1492.

68. Munoz-Perez, J.J.; Tejedor, L.; Medina, R. Equilibrium beach profile model for perched beaches. J. Coast. Eng. 1999, 15, 950-957.

69. de Ruig, J.H.M.; Roelse, P. A feasability study of a perched beach concept in the Netherlands. In Proceedings of the 23rd International Conference on Coastal Engineering, Venice, Italy, 4-9 October 1992; pp. 2581-2598.

70. Spalding, M.D.; Ruffo, S.; Lacambra, C.; Meliane, I.; Hale, L.Z.; Shepard, C.C.; Beck, M.W. The role of ecosystems in coastal protection: Adapting to climate change and coastal hazards. Ocean Coast. Manag. 2014, 90, 50-57. [CrossRef]

71. Ferrario, F.; Beck, M.W.; Storlazzi, C.D.; Micheli, F.; Shepard, C.C.; Airoldi, L. The effectiveness of coral reefs for coastal hazard risk reduction and adaptation. Nat. Commun. 2014, 5, 3794. [CrossRef]

72. Narayan, S.; Beck, M.W.; Reguero, B.G.; Losada, I.J.; Van, B.; Lange, M.; Burks-copes, K.A. The Effectiveness, Costs and Coastal Protection Benefits of Natural and Nature- Based Defences. PLoS ONE 2016, 11, e0154735. [CrossRef]

73. Ondiviela, B.; Losada, I.J.; Lara, J.L.; Maza, M.; Galván, C.; Bouma, T.J.; van Belzen, J. The role of seagrasses in coastal protection in a changing climate. Coast. Eng. 2014, 87, 158-168. [CrossRef]

74. Nesshöver, C.; Assmuth, T.; Irvine, K.N.; Rusch, G.M.; Waylen, K.A.; Delbaere, B.; Haase, D.; Jones-Walters, L.; Keune, H.; Kovacs, E.; et al. The science, policy and practice of nature-based solutions: An interdisciplinary perspective. Sci. Total Environ. 2017, 579, 1215-1227. [CrossRef] [PubMed]

75. Dare, J.L. Alternative Shore Protection Strategies: Innovative Options and Management Issues. Master's Thesis, College of Oceanic and Atmospheric Sciences, Corvallis, OR, USA, 2003; p. 97333.

76. Morris, R.L.; Strain, E.M.A.; Konlechner, T.M.; Fest, B.J.; Kennedy, D.M.; Arndt, S.K.; Swearer, S.E. Developing a nature-based coastal defence strategy for Australia. Aust. J. Civ. Eng. 2019, 17, 167-176. [CrossRef]

77. Boudouresque, C.F.; Pergent, G.; Pergent-Martini, C.; Ruitton, S.; Thibaut, T.; Verlaque, M. The necromass of the Posidonia oceanica seagrass meadow: Fate, role, ecosystem services and vulnerability. Hydrobiologia 2016, 781, 25-42. [CrossRef]

78. Gobert, S.; Cambridge, M.L.; Velimirov, B.; Pergent, G.; Lepoint, G.; Bouquegneau, J.M.; Dauby, P.; Pergent-Martini, C.; Walker, D.I. Biology of Posidonia. In Seagrasses: Biology, Ecology and Conservation; Springer: Dordrecht, The Netherlands, 2006; pp. 387-408. ISBN 1402029837.

79. Cantasano, N. Posidonia oceanica per la difesa degli ambienti. In Proceedings of the SOS Dune, Roma, Italy, 23 October 2009; pp. 170-183. 
80. Campagne, C.S.; Salles, J.M.; Boissery, P.; Deter, J. The seagrass Posidonia oceanica: Ecosystem services identification and economic evaluation of goods and benefits. Mar. Pollut. Bull. 2014, 97, 391-400. [CrossRef]

81. Anderson, M.E.; Smith, J.M. Wave attenuation by flexible, idealized salt marsh vegetation. Coast. Eng. 2014, 83, 82-92. [CrossRef]

82. Boudouresque, C.F.; Meinesz, A. Découverte de l'herbier de Posidonie; Report in Parc National de Port-Cros; European Union Publ.: Brussels, Belgium, 1982.

83. Costanza, R.; D'Arge, R.; Groot, R.; Farberk, S.; Grasso, M.; Hannon, B.; Limburg, K.; Naeem, S.; O’Neill, R.; Paruelo, J.; et al. The Value of the World's Ecosystem Services and Natural Capital. Nature 1997, 387, 253-260. [CrossRef]

84. Greco, P.; Marconi, G.; Rizzo, V. L'impatto Antropico Sull'erosione Costiera-un Caso Emblematico: La Costa Dell'alto Tirreno Cosentino; CNR-IRPI: Perugia, Italy, 1994; Volume 418.

85. US Army Engineer Research and Development Center Coastal and Hydraulics Laboratory, Centro Studi di Ingegneria Ambientale di Pavia. Analisi Regionale del Litorale della Provincia di Cosenza; Facoltà di Ingegneria: Cosenza, Italy, 2002.

86. Regione Calabria-Autorità di Bacino. Interventi A Basso Impatto Ambientale Nella Protezione dei Litorali, Parte Terza, Rapporto Finale, 2010, Lotto Progettuale n.10, Misura 1.4, POR 2004-2006; Regione Calabria-Autorità di Bacino: Regione Calabria, Italy, 2010.

87. Komen, G.J.; Hasselmann, S.; Hasselmann, K. On the existence of a fully developed wind-sea spectrum. J. Phys. Oceanogr. 1984, 4, 1271-1285. [CrossRef]

88. Barstow, S.F.; Athanassoulis, M.; Cavaleri, L. EUROWAVES: Integration of data from many sources in a user-friendly software package for calculation of wave statistics in European coastal waters. In Proceedings of the Oceanology International 2000 Conference, Brighton, UK, 7-10 March 2000; pp. 269-277.

89. Belibassakis, K.A.; Mediterranean, E. Offshore to Nearshore Transformation of Wave Conditions for Exploitation by Nearshore/Coastal Wave Energy Systems. 2012, pp. 1-6. Available online: https://okeanos-dspace.hcmr.gr/ bitstream/handle/123456789/1274/Belibassakis_Eidiki_Synedria_HCMR_2012.pdf?sequence=1 (accessed on 18 September 2020).

90. Sicilian, J.M.; Hirt, C.W.; Harper, R.P. FLOW-3D: Computational Modeling Power for Scientists and Engineers; Flow Science Report, FSI-87-QO-1; Flow Science, Inc.: Santa Fe, NM, USA, 1987.

91. Faraci, C.; Scandura, P.; Foti, E. Evolution of a perched nourished beach: Comparison between field data and numerical results. In Proceedings of the 34th Conference on Coastal Engineering, Seoul, Korea, 15-20 June 2014.

92. Crain, C.M.; Halpern, B.S.; Beck, M.W.; Kappel, C.V. Understanding and managing human threats to the coastal marine environment. Ann. N. Y. Acad. Sci. 2009, 1162, 39-62. [CrossRef]

93. Hughes, T.P.; Bellwood, D.R.; Folke, C.; Steneck, R.S.; Wilson, J. New paradigms for supporting the resilience of marine ecosystems. Trends Ecol. Evol. 2005, 20, 380-386. [CrossRef]

94. Cantasano, N. Il Nostro Mare, La Flora; Doss. W.W.F. Calabr.; World Wildlife Fund: Calabria, Italy, 2008.

95. Cantasano, N. Management Plan for the Beach-Cast Seagrass in Calabria. In Marine Research at CNR; CNR, Dipartimento Terra e ambiente: Roma, Italy, 2011; pp. 1173-1182.

96. Larkum, A.W.D.; Orth, R.J.; Duarte, C. Seagrasses: Biology, Ecology and Conservation; Springer: Dordrecht, The Netherlands, 2006.

97. Dubi, A.M.; Torum, A. Wave damping by kelp vegetation. In Proceedings of the 24th International Conference on Coastal Engineering, Kobe, Japan, 23-28 October 1994; pp. 142-156.

98. Molinier, R.; Picard, J. Recherches sur les Herbiers de Phanérogames Marines du litToral Méditerranéen Français; Masson: Paris, France, 1952.

99. Den Hartog, C. Structure, function, and classification in seagrass communities. In Seagrass Ecosystems: A Scientific Perspective; McRoy, C.P., Helfferich, C., Eds.; Marcel Dekker: New York, NY, USA, 1977; pp. 89-121.

100. Mazzella, L.; Scipione, M.B.; Gambi, M.C.; Buia, M.C.; Lorenti, M.; Zupo, V.; Cancemi, G. The Mediterranean seagrass Posidonia oceanica and Cymodocea nodosa. In A Comparative Overview, Proceedings of the First International Conference on the Mediterranean Coastal Environment, Antalya, Turkey, 2-5 November 1993; MEDCOAST: Wales, Australia, 1993; pp. 103-116.

101. Bellan-Santini, D.; Lacaze, J.-C.; Poizat, C. Les Biocénoses Marine et Littorales de Méditerranée, Synthèse, Menaces et Perspectives; Muséum National d'Histoire Naturelle: Paris, France, 1994; Volume 19, ISBN 2-86515-091-7. 
102. Ballesteros, E. Production of seaweeds in Northwestern Mediterranean marine communities: Its relation with environmental factors. Sci. Mar. 1989, 53, 357-364.

103. Alcoverro, T.; Duarte, C.M.; Romero, J. Annual growth dynamics of Posidonia oceanica: Contribution of large-scale versus local factors to seasonality. Mar. Ecol. Prog. Ser. 1995, 120, 203-210. [CrossRef]

104. Vidondo, B. Duarte Cm Seasonal growth of Codium bursa, a slow-growing Mediterranean macroalga: In situ experimental evidence of nutrient limitation. Mar. Ecol. Prog. Ser. 1995, 123, 185-192. [CrossRef]

105. Balestri, E.; Gobert, S.; Lepoint, G.; Lardicci, C. Seed nutrient content and nutritional status of Posidonia oceanica seedlings in the northwestern Mediterranean Sea. Mar. Ecol. Prog. Ser. 2009, 388, 99-109. [CrossRef]

106. Cardilio, M.; Nicastro, S.; Rende, F.; Innocenti, A.M. Nitric oxide effect in transplanted cuttings of Posidonia oceanica (L.) delile. In Proceedings of the 3rd Mediterranean Symposium on Marine Vegetation, Marseille, France, 27-29 March 2007; pp. 28-33.

107. Kai, D.; Zhang, K.; Liow, S.S.; Loh, J.X. New Dual Functional PHB-Grafted Lignin Copolymer: Synthesis, Mechanical Properties, and Biocompatibility Studies. ACS Appl. Bio Mater. 2019, 2, 127-134. [CrossRef]

108. Stratigaki, V.; Manca, E.; Prinos, P.; Losada, I.J.; Lara, J.L.; Sclavo, M.; Sánchez-Arcilla, A. Large-scale experiments on wave propagation over Posidonia oceanica. J. Hydraul. Res. 2011, 49, 31-43. [CrossRef]

109. Vuik, V.; Jonkman, S.N.; Borsje, B.W.; Suzuki, T. Nature-based flood protection: The efficiency of vegetated foreshores for reducing wave loads on coastal dikes. Coast. Eng. 2016, 116, 42-56. [CrossRef]

110. Vu, M.T.; Lacroix, Y.; Nguyen, V.T. Investigating the impacts of the regression of Posidonia oceanica on hydrodynamics and sediment transport in Giens Gulf. Ocean Eng. 2017, 146, 70-86. [CrossRef]

111. Montefalcone, M.; Morri, C.; Peirano, A.; Albertelli, G.; Bianchi, C.N. Substitution and phase-shift in Posidonia oceanica meadows of NW Mediterranean Sea. Estuarine. Coast. Shelf Sci. 2007, 75, 63-71. [CrossRef]

112. De Villèle, X.; Verlaque, M. Changes and degradation in a Posidonia oceanica bed invaded by the introduced tropical alga Caulerpa taxifolia in the north western Mediterranean. Bot. Mar. 1995, 38, 79-87.

(C) 2020 by the authors. Licensee MDPI, Basel, Switzerland. This article is an open access article distributed under the terms and conditions of the Creative Commons Attribution (CC BY) license (http://creativecommons.org/licenses/by/4.0/). 